\title{
Differences in Portfolios aCross COUNTRIES: \\ ECONOMIC ENVIRONMENT VERSUS HOUSEHOLD CHARACTERISTICS
}

Dimitris Christelis, Dimitris Georgarakos, Michael Haliassos 


\title{
Differences in Portfolios across Countries: Economic Environment versus Household Characteristics
}

\author{
Dimitris Christelis \\ University of Padua, University of Venice “Ca' Foscari”, CSEF and CFS \\ Dimitris Georgarakos \\ Goethe University Frankfurt and CFS \\ Michael Haliassos \\ Goethe University Frankfurt, CFS, CEPR, MEA
}

September 3, 2010

\begin{abstract}
We document and study international differences in both ownership and holdings of stocks, private businesses, homes, and mortgages among households aged fifty or more in thirteen countries, using new and comparable survey data. We employ counterfactual techniques to decompose observed differences across the Atlantic, within the US, and within Europe into those arising from differences in population characteristics and differences in economic environments. We then correlate the latter differences to country-level indicators. Ownership across the range of the assets considered tends to be more widespread among US households. We document that shortly prior to the current crisis, US households tended to invest larger amounts in stocks and smaller ones in homes, and to have larger mortgages in older age, even controlling for characteristics. This is consistent with the high prevalence of negative equity associated with the current crisis. More generally, we find that differences in household characteristics often play a small role, while differences in economic environments tend to explain most of the observed differences in ownership rates and in amounts held. The latter differences are much more pronounced among European countries than among US regions, suggesting further potential for harmonization of policies and institutions.
\end{abstract}

Keywords: Household finance, aging, stockholding, private business, housing, mortgages, counterfactual decompositions.

JEL Classifications: G11, E21 


\section{Acknowledgements}

We are grateful to Richard Blundell, Olympia Bover, Laurent Calvet, Raquel Carrasco, Didier Davidoff, Jacques de Larosière, Harris Dellas, Richard Disney, Christian Gollier, Tullio Jappelli, Robert Kollmann, Julia LeBlanc, Silvia Magri, Costas Meghir, Antonio Mele, Takashi Yamachita, the Editor, and the referees for helpful discussions and suggestions. We are also grateful to participants at the NBER Summer Institute, the CSEF-IGIER conference in Anacapri, the Torino meeting of the AGE RTN, the Luxembourg Wealth Study Conference in Rome, the Bank of Spain Household Finances Conference; and in the seminar series at the Universities of Bath, Bern, Cambridge, ECARES in Brussels, Imperial College, Mannheim, Paris School of Economics, and in the Bank of England for constructive comments. Daniela Dimitrova provided excellent research assistance. We acknowledge with thanks the generous support of Observatoire de l'Erpagne Européenne through a competitive research grant. This work has been supported in part by the Center for Financial Studies (CFS) under the Research Program 'Household Wealth Management'. Christelis was also supported by the European Union under contract HPRN-CT-2002-00235 (Economics of Aging in Europe - AGE). Contacts: Christelis: cdimitri [at] unisa.it; Georgarakos: georgarakos [at] wiwi.uni-frankfurt.de; Haliassos: Haliassos [at] wiwi.uni-frankfurt.de. 


\section{Introduction}

One of the main objectives of a 'single market' as implemented among European Union countries or US states is to ensure that participants or potential entrants in markets for goods and services, labor, assets, and debts face similar market conditions or economic environment, regardless of the country (or region) in which they are located. Such similarity, for which the metaphor of a 'global' or European 'village' is sometimes used, can be facilitated by progressive harmonization of policies and institutional frameworks within which economic agents in different countries operate, and by improved access to markets located in other countries (or regions) within a union. Furthermore, comparable economic environments could lead to similar market outcomes, at least among mature market participants sharing common characteristics. Yet, international comparisons of such market outcomes are often either impossible because of lack of comparable detailed data or complicated because they refer to populations with different configuration of characteristics.

One of the important market outcomes potentially affected by differences in economic environments is the size and composition of household portfolios, the study of which has been attracting increased attention in recent years. ${ }^{1}$ Reasons for such attention include the increasing complexity of these portfolios, the bigger role played by definedcontribution saving vehicles in financing retirement, the implications of population aging for aggregate asset investment, and the rapid pace of financial innovation.

In this paper we add to the literature on household finance by documenting and analyzing international differences in asset and debt market participation and levels of holdings among mature market participants in the US and in twelve European countries 
in 2004-5. We focus our attention on stock holdings (direct plus indirect in the form of mutual funds and retirement accounts), private business ownership, and ownership of primary residence, as well as on mortgages associated with this residence. Our aim is to examine the extent to which older households that have a similar configuration of characteristics and live in different countries differ with respect to ownership and held amounts of the aforementioned assets and mortgages.

The paper has three novel features. First, it uncovers previously unknown patterns of cross-country and interregional differences in household portfolios using a set of three internationally comparable micro-surveys. The surveys are: i) for the US, the Health and Retirement Study (HRS); ii) for England, the English Longitudinal Study of Aging (ELSA); iii) for eleven additional European countries the Survey of Health, Aging and Retirement in Europe (SHARE). Data from these surveys share a common questionnaire design that facilitates the direct cross-country comparison of asset holdings and of the influence of given household characteristics on investment decisions. All three surveys cover those aged fifty or more, i.e., mature market participants who control a large share of society's wealth and face the challenges of retirement financing.

Second, the paper introduces to the field of household finance methods of counterfactual analysis for the purpose of decomposing observed international differences in asset market outcomes into those arising from differences in household characteristics and in the economic environment faced by households of similar characteristics. These methods are already being used in the labor literature to study discrimination or international differences in the relationship between worker characteristics and wages. ${ }^{2}$ The common thread that runs across these different strands of economic literature has to 
do with differences in market conditions faced by agents of given remaining characteristics: men versus women, minorities versus the rest, workers or households in one country or region versus another.

We perform a counterfactual analysis based on quantile regressions that allow us to study differences across the entire distribution of wealth holdings, as opposed to just the mean or median. ${ }^{3}$ We first compare the US against European countries, then different regions within the US, and finally countries within Europe. The within-US comparison will allow us to develop a yardstick by which to assess differences across the Atlantic and within Europe.

We document considerable differences in observed asset market participation rates and levels of participants' holdings, across Europe and the US but also within Europe. These differences arise predominantly from divergent economic environments that households of similar characteristics face. Finally, we link these estimated effects of differences in economic environments faced by households with the same configuration of characteristics to a set of commonly used indicators of the institutional and policy environment in the countries under consideration.

Our results suggest that US households of given characteristics tend to have greater participation probabilities than their European counterparts, often across the range of the assets considered. Furthermore, European asset owners tend to invest smaller (adjusted for PPP) amounts in stocks and larger amounts in real assets (private businesses and primary residence) than US households at comparable positions of the distribution of holdings, even after controlling for differences in the configuration of characteristics in the asset holder pools. We also find that US households face larger outstanding 
mortgages in older age compared to European households of similar characteristics. As a result they were more vulnerable to the risk of negative housing equity shortly prior to the recent financial crisis.

In most cases, international differences in the configuration of characteristics play a small or no role at all in generating observed international differences in asset market behavior. Sometimes, however, estimated differences in market conditions are so pronounced that they would result in even larger actual disparities if it were not for the partly mitigating effect of differences in household characteristics.

In Section 2 we describe the data. In Section 3, we study differences in participation rates in the three assets and in mortgages. In Section 4, we focus on asset owners and decompose observed international differences in amounts of holdings at various percentiles of the distribution of such holdings. We also link results to existing indicators of the state of relevant asset markets and of government policy throughout. Section 5 offers concluding remarks.

\section{The Data}

We use the three most comprehensive data sets on portfolios of households aged 50 and above currently available. These surveys share a common questionnaire design. The HRS surveys US older households every two years since 1992, while the ELSA surveys older households in England starting in 2002 and continuing with a second wave in 2004. Finally, the SHARE, modeled after the HRS and ELSA, collected its first wave of data in 2004 in Sweden, Denmark, Germany, the Netherlands, France, Switzerland, Austria,

Italy, Spain, and Greece, and in 2005 in Belgium. ${ }^{4}$ We use the 2004-5 wave for all 
countries and information on assets and household characteristics derived from a harmonized set of questions.

Table 1 reports participation rates and levels, by quartile of holdings, for three main asset types (stocks, private business, and principal residence); as well as levels of outstanding mortgage debts and net worth, all in PPP-adjusted thousands of 2004 dollars. ${ }^{5}$ Taking Europe as a whole, net worth is somewhat lower than in the US at the median, and considerably so at the $75^{\text {th }}$ quantile. There is considerable variation of net worth within Europe, and country rankings change as we move along the distribution. The lowest median net worth is observed in Sweden and the largest in England. For the $25^{\text {th }}$ quantile, Austria and Belgium provide the two extremes. England comes top for the $75^{\text {th }}$ quantile, followed by Switzerland, while Greece ranks at the bottom.

Ownership of stocks, either direct or indirect through mutual funds and retirement accounts, is greatest in Sweden, Denmark, and in the US. It is smallest in Austria, Italy, Spain, and Greece. Homeownership is highest in Spain and Greece and lowest in Germany, Netherlands, Switzerland, and Austria. The highest rates of business ownership are observed in Sweden and Switzerland, with the US and Denmark a short distance behind them. The lowest rates are observed in Austria and England. Notably, there is immense variation in the prevalence of outstanding mortgages across Europe. Although the average prevalence in Europe is less than half of that in the US, in certain European countries (Switzerland, Denmark, Netherlands, and Sweden) mortgage debts are more widespread than in the US, and even more so than in southern European countries. Ownership rates of all four items differ also by US region, but the range of variation is substantially smaller. 
Turning to the size of asset holdings, we find a stark contrast between real and financial assets. The US dominates every European country in stockholding, and is dominated by the vast majority of European countries in the case of the primary residence. As for mortgages outstanding in older age, we encounter in the US higher amounts than in every European country, except Switzerland. US regions also exhibit some heterogeneity in asset and mortgage holdings, but over a much smaller range than that prevailing in European countries.

\section{Sources of International Differences in Asset Market Participation}

\subsection{Estimation Model and Methodology}

In this section, we decompose differences in observed participation rates into those resulting from different configuration of characteristics in the population and those resulting from international differences in the influence of a given set of characteristics. We will refer to the former as 'covariate effects' and to the latter as 'coefficient effects'. This decomposition is based on a set of probit regressions, where participation in a given asset is regressed on a number of household characteristics.

We use as regressors a broad set of socio-economic characteristics that existing theory and empirical studies suggest as relevant for household asset and debt choices. As these covariates are based on questions harmonized across the three surveys, a high degree of international comparability is achieved. Definitions of variables are included in the Data Appendix, while Table 2 provides summary statistics of covariates across all countries in the sample. 
In particular, we allow for age effects through a $2^{\text {nd }}$ order age polynomial, and for household size, which is likely to determine consumption needs and affect the amount available for saving out of any given amount of resources. Furthermore, we control for the level of education (finished high school/having at least some post secondary education), which tends to influence not only future employment and earnings prospects but also the ability of the household to collect and process information relevant for asset and debt market participation; work status (retired/working/unemployed-other inactive), ${ }^{6}$ which could affect the background income risk to which the household is exposed, which in turn can influence the ownership of different assets or debts; and for marital status (couple/widow/never married), which can determine spending decisions, the responsibilities of the household member in charge of finances, and potential constraints on that member's behavior in asset and debt markets.

We include health conditions, because they can affect household asset choices. ${ }^{7}$ Physical health can influence the ability and inclination of the household to make the effort required for investing in asset markets, as well as the amount of background risk the household faces due to out-of-pocket health expenditures. We use self-reported bad health (includes responses 'fair' and 'poor' in HRS), and, as an objective health indicator, the number of activities of daily living (ADLs) with which the household has problems.

We also control for recall ability, as a measure of cognitive skills relevant to processing information needed for participation in asset and debt markets. ${ }^{8}$ Moreover, we condition on the subjective probability to leave a bequest, in order to account for bequest motives influencing asset ownership; on whether the household provides help to relatives/neighbors, and on whether it engages in volunteering, as indicators of social 
interactions and of concern for others. ${ }^{9}$ Finally, we include income and net wealth quartiles (where wealth excludes the asset in question), in order to capture the relevance of household economic resources for asset and debt demand. Controlling for resources is dictated both by modern portfolio theory, with its emphasis on "cash on hand" as a key state variable for portfolio formation, and by the need to avoid confounding the role of other determinants with that of wealth when the latter is not adequately accounted for.

We first run one probit for each asset in the country used as the 'base'. Table A.13 in the Web Appendix presents a representative set of coefficient estimates. Marginal effects of two included characteristics on the probability of asset and mortgage debt ownership and a comparison of those across countries and instruments are presented in Figures A.9 and A.10 in the Web Appendix. We then construct the counterfactual, $\hat{p}^{i, b a s e}$ , namely the average predicted probability of participation that households in country $i$ would exhibit if they faced the coefficients that were estimated for the base country. The difference in participation rates between the base and country $i$ is then decomposed into two components:

$$
p r^{\text {base }}-p r^{i}=\left\{p r^{\text {base }}-\hat{p}^{i, \text { base }}\right\}+\left\{\hat{p}^{i, \text { base }}-p r^{i}\right\}
$$

The first is due to the difference in participation rates that would have been observed if residents of the base country had the same configuration of characteristics as in country $i$, i.e., it represents the contribution of household characteristics ('covariate effects'). The second is due to the difference in participation that would have prevailed if residents of country $i$ had faced the same coefficients as those in the base country: it reflects the contribution of differences in coefficients ('coefficient effects'). The decomposition yields point estimates of the two effects. We compute bootstrap standard errors by 
drawing (with replacement) from the full sample for both countries and repeating this estimation and decomposition two hundred times.

The more similar the prevailing market conditions in a set of countries or regions (which include the institutional and policy environment), the more similar should be the participation probabilities for households with a given configuration of characteristics and attitudes. Coefficient effects would speak directly to this question. Covariate effects show the extent to which differences in participation probabilities are due to a relatively unfavorable configuration of the characteristics of the population in a particular country or region. We first use the US as 'base' and compare to it European countries. In order to set a realistic benchmark, we then consider coefficient and covariate effects among US regions (using the Midwest as the base region), which share a common federal government but also allow state discretion, especially on fiscal matters. Finally, we do the same analysis within Europe, using Germany as the base.

While precise attribution of coefficient effects to specific features of the market environment in each country is beyond the scope of our paper, we find that the pattern implied by our estimates is consistent with the pattern of various widely-used indicators of institutional and policy features. This in turn implies that harmonized institutions and policies can lead to greater similarity in the link between household characteristics and asset market behavior.

\subsection{US-Europe Comparisons}

Table 3a shows differences in participation rates in three assets and in mortgage debt between the US and twelve European countries, and their decomposition into 
coefficient and covariate effects relating to the economic environment and to population characteristics, respectively. Observed differences in participation rates vary across financial instruments and countries, not only in magnitude but also in sign. In the face of this rich variation in observed differences, population effects are remarkably unidirectional. With only one exception, US households have characteristics that make them more, or at least no less, likely to participate in any of the three assets and to own mortgages on the primary residence. It is differences in the economic environment that are key to generating the rich pattern of sign variation in observed participation differences.

Only Sweden and Denmark exhibit higher stockholding participation rates than the US, and these arise because households of given characteristics are more likely to participate in the stock market if they live in these two countries. So strong is the effect of the environment that it prevails on the opposite influence of population characteristics. In France, the effect of the economic environment is also positive, but not sufficient to overcome the covariate effects, yielding overall lower participation than in the US. The special position of Sweden, Denmark and France seems to be related in part to the state of pension systems. In Sweden and Denmark, retirement accounts are mandatory. ${ }^{10}$ Moreover, these are three of the five European countries in our sample where defined contribution, occupational pension plans were already available in 2004, possibly creating spillovers to forms of stockholding included in our data. ${ }^{11}$

Table 4 presents a set of aggregate indicators relevant to stockholding that are also informative about the economic environment prevailing in each country (additional indicators are provided in the Web Appendix). According to these, the US has the lowest 
transactions costs in the stock market, the greatest spending on information and communication technology as a percentage of GDP, and the highest stockholder protection. All three factors have been shown in existing literature on stockholding to encourage participation. In addition, the extremely high internet penetration in Sweden and the US may have fostered stockholding by lowering information and transaction costs. $^{12}$

We next associate estimated differences in the economic environment to a set of aggregate indicators that reflect certain economic conditions prevailing in each country. Table 5, panel A, presents estimates of a regression of estimated coefficient effects for stock ownership on the following indicators: market capitalization to GDP ratio, the number of Internet connections, a measure of shareholder rights, and an aggregate index of prevailing trust.

With respect to shareholder protection, a frequently used measure is the Antidirector Rights Index (ADRI) introduced by Laporta et al. (1997). Giannetti and Koskinen (2003), using aggregate data from 26 countries, found a positive association between ADRI and stock market participation rates. We employ a revised version of ADRI for 2005 that was recently proposed by Spamann (2009). Our trust measure is a world index of trust constructed from questions in the World Values Survey, which provides internationally comparable data on household values and norms. Guiso et al. (2008) show that the level of trust prevailing in each country is positively associated with the fraction of stock market participants in the population.

Results from robust regressions of our estimated coefficient effects on these aggregate indicators suggest that, controlling for other factors, stronger shareholder rights 
and higher prevailing trust in European countries are associated with smaller differences with respect to the US that are attributable to the economic environment.

Turning to ownership of (at least a share in a) private business, we observe that only Sweden and Switzerland rank above the US. Based on the results of our decompositions shown in Table 3a, however, it is Sweden and Denmark that exhibit significantly higher participation rates for households of a given configuration of characteristics compared to the US. In Switzerland, estimated coefficient effects are negative but statistically insignificant. On the other hand, five European countries exhibit conditions in their economic environment that do not favor participation in private business of similar households compared to the US. This is a richer pattern of variation in effects of the economic environment than for stockholding.

We have examined a number of supply-side indicators that are related to entrepreneurial activity (some of them are shown in Table 4, while the full set is presented in the Web Appendix), to see if they are consistent with the pattern of estimated coefficient effects. The World Bank 'Ease of Doing Business’ overall index points to the US as the country where it is easiest to do business, whereas rankings for the various components of the index do not always place the US at the top. Our estimates suggest that the overall summary index, though useful, may be masking the true underlying variation in market conditions by netting out relevant conflicting differences. Upon close inspection, the index takes a rather simple approach to aggregating rankings across different criteria, namely a straight averaging of rankings, without considering distances and differences in the relative importance of each criterion. For example, Sweden ranks above the US in dealing with licenses, registering property, trading across 
borders, and enforcing contracts. The specific averaging and netting out process puts the US on top, but our estimates imply that certain underlying factors, possibly captured by individual components of the index, dominate and make older Swedish households more likely to participate in private business than their US counterparts.

We also run robust regressions to correlate estimated coefficient effects with some aggregate indices denoting a European country's rank in: i) tax burden; ii) difficulty in getting credit, and iii) difficulty in trading across borders. Results are presented in panel B of Table 5. We find that our estimated differences in economic environment with respect to the US are systematically (positively) related to the tax burden and to the extent of difficulties in getting credit in Europe.

Turning to homeownership, we find that Belgium, Spain, and Greece exhibit higher homeownership rates among older households than the US. While US older population characteristics would result in higher (or at any rate not lower) homeownership rates than in any European country, all three southern European countries, Belgium, and England exhibit higher ownership rates of the primary residence once we compare households with the same configuration of characteristics.

We also associate estimated coefficient effects with two indicators of costs that prospective homebuyers face in each country: a (harmonized) housing price index, and VAT on new homes. Results (presented in panel C of Table 5) suggest that the VAT on home purchases across countries is systematically related to these coefficient effects, and that a higher VAT in Europe would have a statistically significant effect on making economic conditions less conducive for home ownership compared to the US. 
The next panel of Table 3a presents a similar decomposition for mortgages, to see if the pattern we discovered for homeownership is mirrored in the pattern of mortgage participation in older age. Comparing first the observed raw differences in participation, we find that in all European countries where homeownership is higher than in the US, mortgages are less prevalent. In fact, only in Sweden, Denmark, the Netherlands, and Switzerland is mortgage ownership more frequent than in the US.

Secondly, we compare coefficient effects for homeownership and for mortgages. Is it the case that countries with more a favorable economic environment for homeownership are also shown to have more favorable environment for mortgages outstanding, at least as far as older households are concerned? It turns out that in all cases of European countries exhibiting favorable conditions for homeownership relative to the US, the tendency of given older households to have mortgages outstanding is lower than in the US, not higher. In fact, nine of the twelve country pairs exhibit a reversal of signs between the coefficient effects for homeownership and for mortgages. Countries in which older households of given characteristics are more likely to own their home than in the US are also those in which such households are more likely to have paid off their mortgage (if they ever got one) by the time they are included in the sample.

Note that we are controlling for non-housing wealth, so being generally wealthier is not the mechanism generating more limited dependence on mortgages in older age. The shorter duration of mortgages, the greater down-payment ratios, and the smaller frequency of ever having had a mortgage could all contribute to a lower probability of still owing in older age in Europe. 
While it is instructive to look at each asset or debt separately, they form together a single portfolio. There is room for substitution across assets (an issue that we will take up when we look at amounts), as involvement in one market could potentially influence the chances of participating in another. A particularly interesting question is whether homeowners differ from non-homeowners in stockholding participation and its associated coefficient effects. To probe into this issue, we have divided stockholders into homeowners and non-homeowners (results from these decompositions are shown in Table A.7 of the Web Appendix). We find that differences in stockholding participation rates across the Atlantic are typically much larger (and sometimes of different sign) for homeowners than for non-homeowners. Strikingly, in all countries, homeowners exhibit larger differences in stockholding participation for given characteristics (i.e. larger coefficient effects) than non-homeowners.

This finding is consistent with the view that owning a home discourages households from owning stocks. Homeowners in Europe, who are exposed to the conditions in housing and possibly mortgage markets of their countries, apparently find it more difficult to participate in the stock market as well. Indeed, market spillovers are quite consistent with the approach taken in this paper, namely to focus on disparities in the economic environment at large, after removing any influence due to differences in characteristics, rather than exclusively on conditions in a specific market. ${ }^{13}$

\subsection{Similarity of Economic Conditions within the US and within Europe}

In this section, we extend the analysis of the previous section to examine differences within Europe (with Germany as the benchmark); and across four US regions, 
Midwest (MW, used as the base region), Northeast (NE), South (S), and West (W). We do so for two main reasons. First, coefficient effects across the Atlantic look sizeable, but it is useful to put them into perspective by comparing them to an actual case of a more homogeneous economic environment prevailing in a federal country, such as the US. Clearly, zero coefficient effects represent an extreme theoretical benchmark unlikely to be achieved even in such a case. Second, while the US enjoys mobility of labor and capital across geographical regions, a common monetary policy and stock market, and common federal institutions, it also exhibits variation across its States, e.g. with respect to fiscal matters. It is thus worthwhile to see if our method is sensitive enough to pick up significant differences in market conditions arising from such considerations, and how large these effects are compared to those across the Atlantic and across European countries that are part of the European Union (with the exception of Switzerland).

Table 3b shows decompositions of differences in average participation probabilities for each asset and for mortgages within the US. Households in the MW exhibit higher participation rates across the board, with two exceptions: in the NE stockownership is more frequent, and the same is true for mortgages in the West. The bottom panel shows corresponding differences between Germany and each of the European countries in our sample. We see that observed differences in participation within the US are on a much smaller scale compared to inta-European differences, except for the case of business ownership.

Our method is sensitive enough to pick up statistically significant differences in market conditions across US regions for some region/financial instrument combinations. Market conditions in the MW are typically estimated to be more conducive to 
participation in any of these instruments, with two exceptions: stockownership, where the NE dominates; and homeownership, for which the South offers more favorable conditions. However, these intra-US differences pale in comparison to the estimated intra-European differences in the tendency of similar households to own stocks or their primary residence, and to have mortgages outstanding in older age.

The results shown in Table 3b suggest that these sizeable differences in participation rates within Europe are typically not due to statistically significant effects of population characteristics in different European countries relative to Germany. They are rather due to strong coefficient effects, i.e., to differences in the economic environment.

Germany (the base country) is approximately in the middle of the ranking regarding stockholding participation rates. Interestingly, the sign pattern of observed differences in participation is fully reflected in the sign pattern of coefficient effects, with most covariate effects statistically insignificant. The position of Germany in the ranking seems to be reflecting the tendency of given households to participate, rather than a poor composition of the population in terms of characteristics conducive to stockholding.

Germany has the lowest homeownership rate among European countries, as indicated by the negative observed differences in participation rates shown in Table 3b. It is interesting that this negative sign is mirrored in statistically significant negative effects of the economic environment (with the exception of Switzerland), while the pattern of covariate effects is much more mixed and largely insignificant. On the side of mortgages, it is noteworthy that Germany is not the country with uniformly best or worst economic environment: negative coefficient effects on ownership of primary residence are accompanied by coefficient effects for mortgages of mixed sign. This lack of symmetry 
makes clear that the low homeownership rate in Germany does not simply reflect conditions that make it difficult to have an outstanding mortgage in older age.

It seems likely that part of the differences in homeownership rates for households of given characteristics has to do with cultural factors, such as the societal importance of homeownership, that we cannot fully control for by making use of the variables at our disposal. Another part could be due to differential transactions costs, tax treatments, and credit market conditions across Europe. This is indeed suggested by the high cost of housing transactions in Germany and the inability of owners-occupiers therein to deduct mortgage interest, unlike what happens with owners who rent to others. When there is substantial interaction between culture, institutions, and policies, progress towards harmonization of the economic environment is likely to be slower and more cumbersome.

Our findings for private business ownership suggest greater similarity of market conditions in Europe than for the other assets. Coefficient effects are insignificant for about half the country pairs. However, comparison between coefficient and covariate effects for business ownership among older households suggests that the economic environment once again plays a dominant role in determining the sign and overall size of differences in participation rates within Europe.

All in all, we find that intra-European differences are quantitatively significantly larger than intra-US ones for stockholding, home ownership, and mortgages outstanding in older age, though often not for private business ownership. The role of population differences in shaping the overall observed differences in participation rates within the US and within Europe appears much more limited, in terms of statistical significance, sign, and size. 


\section{Sources of International Differences in Levels of Asset Holdings}

We turn now to real, PPP-adjusted levels of asset holdings across the thirteen countries, document their differences, and perform an equivalent decomposition into the part that arises from differences in economic environment and in characteristics of the pool of holders of the four financial instruments. We employ decomposition techniques based on quantile regressions in order to study the entire distribution of holdings across the owner pool in each country. A key advantage of this decomposition is that it allows us to examine whether market conditions facing relatively small holders show greater similarity across countries compared to conditions facing large holders.

\subsection{Estimation Model and Methodology}

We employ a variant of the Machado and Mata (2005) quantile-regression decomposition. ${ }^{14}$ We first estimate ninety nine vectors $j$ of quantile regression coefficients at each single percentile, $\theta_{j}$, of the distribution of the instrument in the base country:

$$
Q_{\theta j}^{\text {base }}\left[y^{\text {base }} \mid X^{\text {base }}\right]=X^{\text {base }} b^{\text {base }}\left(\theta_{j}\right)
$$

We control for the same set of regressors as in the participation probit described in Section 3.1. Table A.14 in the Web Appendix presents sets of median regression estimates, by financial instrument, for the three reference countries or regions: the US, used for US-Europe comparisons; the Midwest (MW), used for within-US comparisons; and Germany, used for comparisons across Europe. 
We then make $m$ random draws, with replacement, of characteristics and corresponding weights from the European country $i$, where $m$ is the number of owners of the instrument in question in the sample from country $i$. This process is repeated ninety nine times. Each outcome of these draws, containing m observations, is denoted by $X_{j}^{i}$. We generate ninety nine counterfactual samples of size $m$ from the desired conditional distribution: $y_{j}^{*}=X_{j}^{i} b^{\text {base }}\left(\theta_{j}\right)$. We use these values to generate the unconditional counterfactual distribution: $f^{*}\left(y ; X^{i} b^{\text {base }}\right)$. Finally, for each of the three sequences of variables (log holdings in the 'base', in country $i$, and counterfactual values), we calculate percentiles using population weights.

The decomposition can be written as:

$$
f\left(y^{\text {Base }}\right)-f\left(y^{i}\right)=\left\{f\left(y^{\text {Base }}\right)-f^{*}\left(y ; X^{i} b^{\text {Base }}\right)\right\}+\left\{f^{*}\left(y ; X^{i} b^{\text {Base }}\right)-f\left(y^{i}\right)\right\}
$$

The densities without asterisk represent the actual levels of the financial instrument in question across their distribution among owners. The starred density is our generated counterfactual. $^{15}$

In order to interpret this decomposition, we can think of starting with the distribution of holdings in a particular country or region $i$ and comparing it to what would have been observed if the population of holders were confronted with the same economic environment facing holders in the base country. The resulting difference (shown in the second bracket) represents these coefficient effects. We then compare the counterfactual to the actual density in the base country. This difference (shown in the first bracket) represents covariate effects, i.e. those attributable to differences in configuration of characteristics between owners in country or region $i$ and those in the 'base' one. 
We also compute and present confidence bands for covariate and coefficient effects based on bootstrapped standard errors. These are calculated by first generating one hundred bootstrapped samples from the original sample of owners. Then, by repeating the process described above one hundred times, we generate a series of one hundred bootstrapped counterfactual distributions and use them to estimate standard errors.

We have performed several robustness checks, which have yielded results very similar to those presented here (details can be found in the Web Appendix). An issue of potential concern is selectivity and its possible effects on the estimates of the covariate and coefficient effects. Given the lack of a generally accepted method of handling selectivity in quantile regression, we examined whether decompositions of mean differences in amounts are sensitive to selectivity. Specifically, we applied the selectivitycorrected decompositions proposed by Neuman and Oaxaca (2004) and found that they give quite similar results to decompositions of mean differences that ignore selectivity (see Web Appendix, section IV for a fuller discussion). Thus, we doubt that our main conclusions about holdings are affected by this issue.

\subsection{Europe versus the US}

Table 6a shows coefficient and covariate effects for stockholding, private businesses, primary residence, and mortgage levels in older age. For brevity, we present results for the three quartiles only. In the Web Appendix, we present graphs depicting the entire distribution of holdings for each country/ financial instrument combination examined.

Before going into details for each financial instrument, two important general 
observations can be made. First, we find effects of the economic environment that are typically large (in absolute value) and almost always statistically significant. Our estimation also picks up a number of instances with statistically significant effects of characteristics of the owner pools, but estimates are typically smaller and, in several instances, statistically insignificant.

Second, unlike covariate effects, those of the economic environment are always of the same sign as overall observed differences in holding levels, sharing a common pattern. Indeed, in some cases (such as that of the primary residence), effects of owner characteristics point in the opposite direction of overall observed differences, but estimated effects of the economic environment are sufficiently large to overwhelm this opposite influence of characteristics, often by a large margin. It is in this sense that conditions of the economic environment are estimated to set the pattern of overall international differences in levels of holdings.

\subsubsection{Stockholding}

The first panel of Table 6a shows results for stock amounts, directly and indirectly held. US stockholders hold greater amounts of stock wealth across the distribution of stock holdings compared to any European country (except for Switzerland that exhibits larger holdings; and for Denmark, where holdings are similar). With the exception of Sweden (and possibly Spain), this difference is fundamentally attributable to effects of differences in the economic environment across all quantiles, with covariate effects close

to zero. This means that, despite typically lower European stock holdings, European stockholders would achieve considerably higher levels if they were confronted with the US economic environment. Sweden also exhibits significant coefficient effects in this 
direction, but a large part of its observed difference in amounts invested in stocks relative to the US is attributable to the characteristics of its stockholder pool. This is an important consequence of the fact that stock market participation is more widespread in Sweden than in the US, and thus the composition of the Swedish stockholder pool is more diluted by households whose characteristics are less conducive to stockholding compared to their US counterparts. Our findings for the dominant role of coefficient effects seem quite consistent with equity market indicators compiled by the World Bank and other sources (Table A.1 in the Web Appendix). Austria, Greece, and Denmark exhibit the three lowest scores in terms of the World Bank stock market size indicator, which comprises market capitalization, value of stocks traded, and turnover ratios. At the other extreme, Switzerland ranks at the top of this index. Low stockholding levels are observed in countries exhibiting poor institutional characteristics, such as high transactions costs and limited shareholder rights, rather than being closely linked to properties of stock returns (as reflected in the volatility and market stability measures).

Table 7, panel A summarizes results from a regression of coefficient effects estimated at different points of the asset amount distribution (i.e. indicative of the economic environment faced by both smaller and larger holders) on a set of country level indicators. Results suggest that shareholder rights and aggregate indicators of trust contribute to explaining the pattern of estimated coefficient effects across countries: higher ADRI and trust indicators in Europe tend to lead to narrowing of differences in economic environment that contribute to differences in stock holdings of small and medium investors. Relevant differences in economic environment can also be linked to the scale of stock markets (measured by the market capitalization to GDP ratio) and to the 
number of internet connections in the European country. Both reduce differences in stockholding amounts from the US at comparable points in the distributions of holdings.

We also break up the sample of stockholders into those who are homeowners and those who are not (detailed results are presented in Table A.8 in the Web Appendix). Quite analogously to what we found for participation, differences between the US and European countries in amounts of stocks held tend to be larger when we focus on homeowners, and this applies also to coefficient effects. These findings are consistent with the view that Europeans regard investment in the home as a partial substitute for investment in stocks. Moreover, differences in the economic environment discourage European homeowners from larger exposures to the stock market more than they discourage US homeowners.

\subsubsection{Private Businesses}

The second panel of Table 6a shows observed differences and counterfactual decompositions for private business holdings among older owners. There is considerable variety in observed differences in holdings across the Atlantic. Swedish and Danish older owners of private businesses invest more than US owners across the entire distribution of holdings, but US holdings dominate those found in most other countries. Furthermore, there is not a clear pattern in the relationship between size of holdings and size of differences. There are cases, such as England or France, where differences are largest at the low end of holdings, vanishing at the upper end. There are other cases, where differences seem quite uniform over the distribution of amounts, such as Germany. Finally, in countries such as Spain, these differences increase with the size of holdings. 
Differences in economic environment tend to have statistically significant effects for smaller holders in the vast majority of countries, while statistical significance is attenuated for median and large holdings, with about half the countries exhibiting significant effects.

The lack of definite pattern in Europe-US comparisons of private business holdings is consistent with the observation made in the section on participation that the top place of the US in the overall index of ease of doing business masks considerable diversity of rankings in the various components of the index.

Results from robust regressions of coefficient effects on aggregate indicators (panel B, Table 7) suggest that a higher tax burden and difficulties in trading across borders in Europe are associated with larger differences in amounts invested in business compared to the US.

\subsubsection{Value of the Main Residence}

The third panel of Table 6a shows differences between the US and European countries in real gross values of the primary residence. In eight of the twelve countries considered, European homeowners invest larger amounts in their primary residence than US homeowners at the same point in the home value distribution. In only three cases (Sweden, Greece, and Spain for higher quantiles) are amounts invested larger among US owners than among European owners. The picture is even more striking when we decompose differences into coefficient and covariate effects. In all cases, characteristics of US homeowners push in the direction of larger investments in the primary residence. However, in ten of the twelve cases, Europeans of given characteristics tend to invest 
larger real amounts in the primary residence than US households with similar characteristics. Of the remaining two cases (Sweden and Denmark), only Swedish households tend to invest strictly less in the home than US homeowners of similar characteristics.

To be sure, larger real holdings do not represent, on average, larger homes in Europe than in the US. As is well known (and further documented in Table A.3 in the Web Appendix), there is a large leap in the average size of dwellings when crossing the Atlantic. Europeans simply tie up larger real amounts in their primary residence compared to US homeowners of similar characteristics and position in the distribution of home values.

We view this as an intriguing finding unlikely to have a simple explanation, primarily because of how widespread the tendency is for Europeans to have larger amounts invested in the house. It seems unlikely that the difference is simply pricerelated. While there are areas in the US where land is abundant and house prices relatively low, the data include also homeowners from the $\mathrm{W}$ and the $\mathrm{NE}$, where land is highly priced. While there are countries in Europe affected by a shortage of land (such as the Netherlands), and a number of countries that have experienced strong booms in real housing prices (especially Spain, UK, the Netherlands and Italy), the finding applies also to Germany, which exhibits stagnant or even declining house prices.

Another possibility would be a uniformly more favorable tax treatment of housing in Europe. However, according to various features of the taxation system for residential property (summarized in Table A.4 in the Web Appendix), there is not such a clear favorable treatment. One possible exception is non-taxable capital gains, but again this 
applies only to some European countries. Paying larger amounts for the house (given household resources) is also unlikely to be linked to greater availability of large mortgages in Europe: loan to value ratios in mortgage markets are generally lower - or at least no higher - in Europe compared to the US (characteristics of mortgage markets are summarized by Table A.5 in the Web Appendix). We return to mortgages below. Finally, the possibility that the European preference for greater housing investment is linked to motives to give bequests or housing gifts, which tend to be more widespread in Europe than in the US, is weakened by the fact that we are already controlling for survey responses indicating the probability to leave a bequest. Greater prevalence of such factors would thus be captured in the configuration of covariates, which has been taken into account when deriving coefficient effects

Table 7, panel C, summarizes results from regression analysis that associates coefficient effects in the housing market with a harmonized housing price index, and with the VAT on new homes. These suggest that increases in house prices or in VAT in European countries are likely to be associated with relatively smaller home investments by households therein, thus decreasing the distance from similar US households.

\subsubsection{Value of Mortgages for Main Residence}

Is the European tendency to invest more in the home mirrored by a tendency to hold larger mortgages in older age? The fourth panel of Table 6a compares mortgage holders in Europe and in the US and suggests that the answer to this question is negative, with Switzerland being the only exception. 
Going one step beyond observed differences, we see that mortgage owner characteristics contribute very little to the larger outstanding mortgages of US mortgage owners. The bulk of the difference is linked to the market conditions faced by holders of given characteristics. Mortgage holders in the US end up holding significantly larger mortgages to older age compared to European households with a similar configuration of characteristics. As these are equilibrium amounts, they partly reflect a tendency of the US financial sector to allow larger mortgages for owners of similar characteristics.

These larger mortgages may in turn reflect longer durations of mortgages in the US (e.g. 30 versus 15 or 20 years), larger initial loan-to-value ratios, or more pronounced tendencies to move to more expensive homes, taking mortgages to finance the upgrade. Regardless of the precise mechanism, our findings suggest that US households were more exposed to the risk of negative home equity in 2004/5, i.e. shortly before the current financial crisis, than their European counterparts, as they tended to have both smaller home values and larger outstanding mortgages for given household characteristics.

\subsubsection{Do Differences Simply Reflect Pension Wealth?}

As our samples consist of households aged 50 and above, one may suspect that the international differences in asset holdings we found simply reflect differences in pension wealth levels. For example, larger investments in stocks or in homes in one country relative to another may be reflecting generally lower levels of pension wealth in that country. To examine this possibility we calculate two measures of pension wealth that we add to our net wealth measures and redo the main asset decompositions (details on the calculation of the pension wealth measures are provided in the Data Appendix). We 
derive qualitatively similar results to those we present suggesting a strong role for the economic environment even when household heterogeneity with respect to pension wealth is taken into account (results are discussed in section III of the Web Appendix and presented in Tables A.9-A.12).

\subsection{Similarity of Economic Conditions within the US and within Europe}

Table 6b shows decomposition of differences by quartile and by asset or debt, both within the US and within Europe. A number of patterns emerge. First, observed differences in amounts held tend to be smaller and less likely to be significant within the US than across European countries. Second, coefficient effects are more likely to be significant when comparing real assets (homes and private businesses) than when comparing financial instruments (stocks and mortgages).

This is consistent with intuition, as financial markets tend to be more integrated than housing or private business markets. Those having a primary residence in a particular region face the local housing market conditions. There are divergent indicators of housing market conditions within the US, such as lower prices and higher vacancy rates in the MW and in the S (the relevant data are provided in the Web Appendix). In order for these to be similar across regions, households need to be willing and able to move to where the housing market offers better terms. Even if the policy and institutional framework governing housing markets were fully harmonized across states or countries, differences could still arise because of differential employment opportunities or quality of factors complementary to housing (e.g. school quality). It is also expected that market conditions governing private business holdings turn out to be less homogeneous than 
those for stockholding and more homogeneous than housing. This market is less segmented than the housing market, because a household does not need to own a private business where its members want to live. However, supervision, control, and any participation in management of the business are considerably facilitated by geographical proximity. This results in some market segmentation, the effects of which show up in our findings.

The US is a federal country with fiscal federalism and monetary policy run by the Fed. In Europe, monetary union encompasses most of the countries in our sample (except for Sweden, Denmark, Switzerland, and England), while fiscal policies (determining, inter alia, the tax treatment of homes and of private businesses) are far less integrated. This asymmetry is currently being scrutinized, but fiscal union seems a remote prospect.

Stocks are the asset for which coefficient effects were largely insignificant within the US, but this is not the case for Europe (panel A, Table 6b). The vast majority of countries exhibit strongly significant effects, both statistically and economically. Very few covariate effects turn out to be significant, practically all in favor of the German stockholder pool being conducive to larger holdings. Strong coefficient effects for financial assets suggest that European households neither invest in the same stock market nor do they consider the full spectrum of European markets as equally accessible to them, even after the adoption of the euro. This finding is noteworthy, as it does not seem to be confined to small holders: coefficient effects tend to persist at the upper end of the distribution.

For private businesses, we find statistically significant coefficient effects across Europe at various parts of the distribution (panel B, Table 6b). Coefficient effects for 
home values are statistically significant across the whole distribution (panel C, Table 6b). However, their estimated size and sign exhibit much greater variation across European countries. This is so, even though Germany has the lowest homeownership rate in the group and one might a priori assume that it offers uniformly less favorable conditions to homeowners. Analysis of mortgage levels in older age suggests that Germany does not offer the worst prospects for large mortgages in older age compared to several countries in Europe, despite its very low homeownership rate (panel D, Table 6b). This reinforces the points made in the participation section above, pointing to the observation that Germany did not have the lowest prevalence of mortgages among the European countries, nor the worst conditions for households of given characteristics to obtain a mortgage.

\section{Concluding Remarks}

In this paper, we have used internationally comparable micro-survey data across thirteen countries to document and study sources of differences in portfolios of older households across the Atlantic, within the US, and within Europe. We focused our attention on the question of whether households possessing similar configuration of characteristics tend to form similar portfolios across these countries or regions. We applied modern techniques of counterfactual analysis to examine the role of differences in the economic environment governing household ownership of, and investment in, stocks, private businesses, and homes, as well as outstanding mortgages, controlling for a range of observable household characteristics.

We show that households of comparable characteristics tend to have quite different probabilities of participating in a given asset, and also quite different PPP-adjusted 
holdings, both across the Atlantic and within Europe. In most cases, participation probabilities are greater in the US than in Europe. However, the same is not true for the levels of asset holdings. European asset owners tend to invest smaller real amounts in stocks and larger amounts in the primary residence than US households at comparable positions of the distribution of holdings, even after controlling for any differences in the configurations of characteristics in the owner pools. We also document that older US households had substantially higher mortgages relative to their European counterparts, even after controlling for observable household characteristics, and this took place shortly prior to the current financial crisis that created negative equity for many homeowners.

By probing further into the stockholding decisions of home owners and non homeowners, we obtain results consistent with the view that Europeans tend to substitute investment in their primary residence for investment in stocks. This substitution arises, at least in part, from differences in the economic environment that seem to discourage European homeowners from a larger exposure to the stock market in comparison to their US counterparts.

Our findings suggest that international differences in the configuration of owner pools play minimal or no role in generating observed differences in levels of asset and mortgage holdings, often pointing in the opposite direction of observed differences. Differences in conditions of the economic environment not only dictate observed differences but are also substantially more pronounced among European countries than among US regions, suggesting considerable potential for further integration and harmonization of economic environments within which households operate. 
Nevertheless, our analysis is positive rather than normative. Finding differences in economic environment does not necessarily imply that they should be eliminated through institutional reform and policy harmonization. Promoting holdings of particular assets or debts can be a political choice. Our findings provide a check on consistency between stated objectives and observed outcomes and point to statistically and economically significant differences in market conditions, both across the Atlantic and within Europe, much more so than within the US.

Our study could encourage work in various directions. The pattern of coefficient effects between Europe and the US, signaling reversals between financial and real assets, as well as the pattern for smaller country groups present compelling challenges for future research aimed at further identifying their sources, likely persistence, and amenability to policy interventions. Our approach could be applied to analyzing market conditions for other assets or debts; other country groupings (for example, comparable surveys are currently being designed or taking place in Japan, Korea, China, and India); and demographic groups of interest, both within a given country and across countries. Finally, it could be applied to studies of the evolution and convergence of market conditions through time.

Ultimately, recently available data and modern counterfactual methods of analysis can contribute to our understanding of the extent to which 'single market programs' aimed at the creation of areas without internal frontiers and with free movement of goods, persons, services, and capital have succeeded in transforming national residents into citizens of a global - or at least international - 'village', facing similar economic environments, policies and constraints regardless of the country in which they reside. 


\section{References}

Albrecht, James, Anders Björklund, and Susan Vroman (2003). “Is There a Glass Ceiling in Sweden?”, Journal of Labor Economics, 21, 145-77.

Arulampalam, Wiji, Alison L. Booth, Mark L. Bryan. (2007). "Is There a Glass Ceiling over Europe? Exploring the Gender Pay Gap across the Wage Distribution”, Industrial and Labor Relations Review, 60(2): 163-86.

Autor, David H., Lawrence F. Katz, and Melissa S. Kearney (2008). "Trends in U.S. Wage Inequality: Revising the Revisionists", The Review of Economics and Statistics, 90(2): 300-23.

Bilias, Yannis, Dimitris Georgarakos and Michael Haliassos (2006). "Equity Culture and the Distribution of Wealth”, mimeo, Goethe University Frankfurt.

Bilias, Yannis, Dimitris Georgarakos and Michael Haliassos (2010). "Portfolio Inertia and Stock Market Fluctuations”, Journal of Money, Credit and Banking, 42(4): 715-742.

Bogan, Vicky (2008). “Stock Market Participation and the Internet”, Journal of Financial and Quantitative Analysis, 43, 191-212.

Börsch-Supan, Axel, Agar Brugiavini, Hendrik Jürges, Johan Mackenbach, Johannes Siegriest, and Guglielmo Weber (2005), Health, Aging and Retirement in Europe: First Results from the Survey of Health, Aging and Retirement in Europe. Mannheim: Mannheim Research Institute for the Economics of Aging.

Campbell, John Y. (2006). “Household Finance”, Journal of Finance, 61, 1553-604.

Campbell,John Y., and João F. Cocco (2003). "Household Risk Management and Optimal Mortgage Choice”, Quarterly Journal of Economics, 118, 1449-94.

Campbell, John Y. and Luis Viceira (2002). Strategic Asset Allocation: Portfolio Choice for Long-term Investors, Oxford: Oxford University Press.

Christelis, Dimitris, Tullio Jappelli and Mario Padula (2010). "Cognitive Abilities and Portfolio Choice”, European Economic Review, 54, 18-38.

Cocco, João F. (2005). "Portfolio Choice in the Presence of Housing", Review of Financial Studies, 18, 535-67. 
Cocco, João F., Francisco Gomes, and P.J. Maenhout (2005). “Consumption and Portfolio Choice over the Life Cycle”, Review of Financial Studies, 18:2, 491533.

Gale, William G., and Karen M. Pence (2006). “Are Successive Generations Getting Wealthier, and If So, Why? Evidence from the 1990s”, Brookings Papers on Economic Activity: 155-234.

Gollier, Christian (2001). The Economics of Risk and Time, Cambridge, MA: MIT Press.

Gomes, Francisco and Alexander Michaelides (2005). "Optimal Life-Cycle Allocation: Understanding the Empirical Evidence”, Journal of Finance, 60, 869-904.

Guiso, Luigi, Michael Haliassos, and Tullio Jappelli (2001). Household Portfolios, Cambridge, MA: MIT Press.

Haliassos, Michael (2008). "Household Portfolios", in S. Durlauf and L. Blume, The New Palgrave Dictionary of Economics, $2^{\text {nd }}$ Edition, Palgrave Macmillan.

Haliassos, Michael and Carol C. Bertaut (1995). “Why Do So Few Hold Stocks?” The Economic Journal, 105, 1110-29.

Haliassos, Michael and Alexander Michaelides (2003). "Portfolio Choice and Liquidity Constraints”, International Economic Review, 44, 143-78.

Heaton, John and Deborah Lucas (2000a). "Portfolio Choice in the Presence of Background Risk”, The Economic Journal, 110, 1-26.

Heaton John, and Deborah Lucas (2000b). “Asset Pricing and Portfolio Choice: The Importance of Entrepreneurial Risk,” Journal of Finance, 55, 1163-98.

Helliwell, John F. (1998). How Much Do National Borders Matter? Washington, D.C.: Brookings Institution Press.

Heston, Alan, Robert Summers and Bettina Aten (2006). Penn World Table Version 6.2, Center for International Comparisons of Production, Income and Prices at the University of Pennsylvania.

Kapteyn, Arie, James P. Smith, Arthur H. O. Van Soest, and James W. Banks (2007). "Labor Market Status and Transitions During the Pre-Retirement Years: Learning from International Differences” NBER Working Paper Series, w13536. 
Kaufmann, Daniel, Aart Kraay, and Massimo Mastruzzi (2007). "Governance Matters VI: Governance Indicators for 1996-2006”, World Bank Policy Research Working Paper No. 4280.

King, Mervyn and Jonathan Leape (1984). "Wealth and Portfolio Composition: Theory and Evidence”, NBER Working Paper No. 1468.

La Porta, Rafael, Florencio Lopez-de-Silanes, Andrei Shleifer and Robert W. Vishny (1998). "Law and Finance”, Journal of Political Economy, 106, 1113-1155.

Lewis, Karen K. (1999). "Trying to explain home bias in equities and consumption”, Journal of Economic Literature, 37, 571-608.

Mankiw, N. Gregory and Stephen Zeldes (1991). "The Consumption of Stockholders and Non-Stockholders”, Journal of Financial Economics, 29, 97-112.

Machado, José and José Mata (2005). "Counterfactual Decomposition of Changes in Wage Distributions Using Quantile Regression”, Journal of Applied Econometrics, 20(4), 445-65.

McCallum, John (1995). “National Borders Matter: Canada-U.S. Regional Trade Patterns”, American Economic Review, 85, 615-23.

Neuman, Shoshana and Ronald Oaxaca (2004). "Wage decompositions with selectivitycorrected wage equations: A methodological note”, Journal of Economic Inequality, 2, 3-10.

Spamann, Holger (2009). "The "Antidirector Rights Index" Revisited”, Review of Financial Studies, 23(2), 467-486.

Taylor, Alan M. and Mark A. Taylor (2004). “The Purchasing Power Parity Debate”, Journal of Economic Perspectives, 18, 135-58. 


\section{Data Appendix}

Stocks: all forms of direct and indirect holdings, except for occupational definedcontribution pension plans (for which respondents are not asked directly in our sources).

Private business: value of business net of any related debts.

Principal residence: current value of the house that respondents own and in which they live.

Mortgage debt: outstanding amount of all mortgages and any other loans on the primary residence.

Net worth: the current value of all real and financial assets of the household minus the outstanding amounts of mortgage loans and all other debts.

Household income: total household income from all sources net of capital income.

Age: average age of the two partners in the couple or the age of the household heads if they don't have a partner,

Household size: number of all persons in the household.

Work status: Retired [ $=1$ if both partners in a couple are retired]; Working [ $=1$ if any of the two partners is currently working]; Unemployed-other inactive (omitted category). Definitions are analogous for single heads.

Marital status: Couple [=1 if respondents and their partners live together/ married]; Widow [ $=1$ if the partner has died]; Never married [ $=1$ if respondent has never married]; divorced (omitted category).

Education: High school education [ $=1$ if the highest educational certificate of any of the two partners is a high school degree, and none of the two has attended any postsecondary educational institution]; Post-secondary education [=1 if any of the two partners has had at least some post-secondary education]; Less than high school education (omitted category). Definitions are analogous for single heads.

Recall score: respondents are read ten words and are then immediately asked to repeat them, with the score in the recall test being equal to the number of correctly remembered words. For couples, the value of the variable is equal to the maximum score of the two partners, while for single heads it is equal to the individual score. 
Expectation to leave a bequest: reported probability of leaving a bequest (highest reported probability of the two partners). For single heads, it is equal to their reported probability.

Self-reported Health Fair or Bad: $=1$ if any of the two partners (or the single head) report 'fair' or 'poor' health; 'good', 'very good' or 'excellent' health form the omitted category.

Number of ADL's: number of daily activities that the two partners (or the single head) face difficulties with.

Provides Help to Others: $=1$ if any of the two partners (or the single head) provides help to friends, relatives or neighbors in the month prior to the interview.

Engages in Voluntary Activities: $=1$ if any of the two partners (or the single head) has done any voluntary or charity work in the month prior to the interview.

Pension Wealth: we consider persons having any sort of public pensions and persons with no public pensions that are older than 65 (on the assumption that if they have not received any pension by that age, they are unlikely to receive it in the future). We then take the annual sum of all the included pension items (adjusted for PPP), increase it by a fixed percentage per year (in real terms) for all the years the person is expected to live (we get this information, by age and gender, from the lifetables for each country), we discount each future amount back to the present at a real rate of interest equal to three percent per year, and then sum all the discounted future pension amounts. We consider two cases for the fixed yearly real increase of the pension items: the first case entails no increase, and the second entails a one percent increase. For the US we consider only the first case, as public pensions therein are fixed in real terms.

The pension items included are: i) for the HRS the Social Security pension and any disability pension; ii) for ELSA, the main pension, the incapacity benefit, the war pension, the severe dismemberment allowance, and the disability living allowance; iii) for SHARE, the main pension, any other public early retirement pension, a widow's pension, the war pension, and the disability pension. 
Table 1: Ownership rates and amounts by quartiles

\begin{tabular}{|c|c|c|c|c|c|c|c|c|c|c|c|c|c|c|c|c|c|c|c|c|}
\hline \multirow{3}{*}{$\begin{array}{l}\text { Country/ } \\
\text { Region }\end{array}$} & \multirow{3}{*}{$\begin{array}{l}\text { Number of } \\
\text { Households }\end{array}$} & \multirow{2}{*}{\multicolumn{3}{|c|}{$\begin{array}{c}\text { NET WORTH } \\
\text { Quantiles }\end{array}$}} & \multicolumn{4}{|c|}{ STOCKS } & \multicolumn{4}{|c|}{ OWN BUSINESS } & \multicolumn{4}{|c|}{ HOME } & \multicolumn{4}{|c|}{ MORTGAGE } \\
\hline & & & & & \multirow{2}{*}{$\begin{array}{c}\text { Prevalence } \\
(\%)\end{array}$} & \multicolumn{3}{|c|}{ Quantiles among owners } & \multirow{2}{*}{$\begin{array}{c}\text { Prevalence } \\
\mathbf{( \% )}\end{array}$} & \multicolumn{3}{|c|}{ Quantiles among owners } & \multirow{2}{*}{$\begin{array}{c}\text { Prevalence } \\
(\%)\end{array}$} & \multicolumn{3}{|c|}{ Quantiles among owners } & \multirow{2}{*}{$\begin{array}{c}\text { Prevalence } \\
(\%)\end{array}$} & \multicolumn{3}{|c|}{ Quantiles among holder } \\
\hline & & 25 & 50 & 75 & & 25 & 50 & 75 & & 25 & 50 & 75 & & 25 & 50 & 75 & & 25 & 50 & 75 \\
\hline United States & 13,073 & 40.0 & 162.1 & 437.0 & 49.7 & 11.0 & 49.5 & 169.0 & 9.8 & 40.0 & 100.0 & 350.0 & 77.3 & 80.0 & 150.0 & 250.0 & 38.3 & 32.0 & 70.0 & 125.0 \\
\hline Midwest & 3,170 & 52.0 & 178.2 & 428.1 & 54.5 & 10.0 & 45.0 & 150.2 & 13.8 & 50.0 & 150.0 & 400.0 & 80.9 & 82.0 & 132.0 & 200.0 & 39.3 & 30.0 & 65.0 & 105.0 \\
\hline Northeast & 2,125 & 39.7 & 193.5 & 475.9 & 54.7 & 11.0 & 52.0 & 172.5 & 6.8 & 40.0 & 100.0 & 300.0 & 70.6 & 92.0 & 190.0 & 340.0 & 32.5 & 32.0 & 70.0 & 124.0 \\
\hline South & 5,138 & 29.9 & 113.0 & 326.0 & 42.6 & 10.0 & 43.9 & 153.0 & 9.3 & 25.0 & 90.0 & 250.0 & 78.3 & 63.0 & 100.0 & 180.0 & 36.5 & 28.5 & 58.0 & 102.0 \\
\hline West & 2,399 & 53.0 & 228.5 & 582.0 & 52.1 & 14.0 & 53.3 & 182.5 & 8.6 & 30.0 & 100.0 & 300.0 & 76.9 & 140.0 & 250.0 & 400.0 & 46.0 & 50.0 & 100.0 & 178.7 \\
\hline Europe & 25,394 & 28.4 & 147.6 & 307.5 & 27.0 & 3.6 & 10.6 & 31.0 & 6.4 & 21.4 & 63.8 & 206.9 & 68.3 & 109.8 & 178.3 & 291.1 & 14.9 & 12.3 & 36.0 & 76.6 \\
\hline Sweden & 2,140 & 22.5 & 90.6 & 219.7 & 70.8 & 4.0 & 12.1 & 33.3 & 12.9 & 72.6 & 343.1 & 939.3 & 68.9 & 51.2 & 92.1 & 153.5 & 40.2 & 15.2 & 30.7 & 57.0 \\
\hline Denmark & 1,176 & 14.7 & 102.9 & 258.6 & 56.1 & 2.7 & 8.3 & 22.7 & 9.6 & 84.4 & 337.7 & $1,688.4$ & 69.2 & 90.8 & 136.2 & 204.2 & 44.3 & 28.4 & 56.7 & 90.8 \\
\hline Germany & 2,002 & 11.8 & 95.4 & 272.6 & 25.4 & 3.5 & 9.4 & 26.2 & 6.5 & 21.0 & 52.4 & 151.7 & 51.2 & 136.3 & 209.7 & 314.6 & 14.8 & 12.6 & 36.7 & 83.3 \\
\hline Netherlands & 1,954 & 9.6 & 140.4 & 336.4 & 24.9 & 4.6 & 15.2 & 42.1 & 6.9 & 18.2 & 75.9 & 505.9 & 55.2 & 192.3 & 253.0 & 374.4 & 43.1 & 23.8 & 54.6 & 110.4 \\
\hline Belgium & 2,532 & 96.6 & 199.4 & 370.0 & 37.7 & 5.1 & 20.4 & 69.6 & 5.5 & 63.7 & 128.5 & 308.3 & 80.0 & 127.4 & 173.6 & 254.8 & 11.9 & 5.2 & 14.4 & 32.7 \\
\hline France & 2,110 & 49.4 & 177.1 & 348.9 & 43.0 & 2.7 & 8.5 & 26.6 & 6.0 & 9.8 & 61.7 & 208.8 & 72.2 & 124.1 & 186.2 & 310.4 & 11.9 & 7.9 & 23.7 & 51.7 \\
\hline Switzerland & 712 & 35.5 & 198.4 & 419.3 & 36.3 & 7.2 & 25.5 & 89.3 & 10.9 & 54.6 & 117.1 & 351.9 & 54.8 & 229.5 & 317.4 & 459.1 & 45.3 & 51.0 & 104.6 & 201.3 \\
\hline Austria & 1,409 & 9.4 & 112.5 & 244.5 & 10.2 & 3.0 & 8.1 & 27.4 & 4.1 & 45.9 & 81.0 & 216.0 & 56.7 & 108.0 & 162.0 & 270.0 & 9.2 & 1.9 & 10.8 & 43.2 \\
\hline Italy & 1,778 & 46.4 & 149.5 & 297.2 & 10.4 & 4.7 & 14.1 & 36.1 & 6.5 & 15.4 & 58.3 & 120.0 & 75.1 & 95.4 & 168.7 & 281.2 & 5.6 & 9.6 & 27.0 & 56.2 \\
\hline Spain & 1,753 & 73.2 & 140.7 & 254.1 & 12.8 & 3.9 & 11.0 & 24.7 & 6.7 & 30.2 & 57.7 & 117.1 & 86.9 & 84.1 & 131.3 & 219.7 & 9.7 & 9.5 & 30.2 & 58.6 \\
\hline Greece & 1,982 & 55.8 & 111.7 & 215.6 & 10.6 & 1.1 & 4.7 & 12.4 & 6.6 & 37.2 & 93.1 & 437.7 & 84.3 & 62.0 & 95.5 & 148.9 & 5.5 & 5.0 & 18.6 & 37.2 \\
\hline England & 5,721 & 75.7 & 257.4 & 443.3 & 39.4 & 4.6 & 15.6 & 52.1 & 2.5 & 6.1 & 38.3 & 268.1 & 76.1 & 191.5 & 275.7 & 398.3 & 16.8 & 10.7 & 27.6 & 63.3 \\
\hline
\end{tabular}

Note: Weighted statistics using 2004 HRS, SHARE and ELSA data. All amounts are in thousand of PPP-adjusted dollars. PPP exchange rates are taken from the Penn World Tables, version 6.2 (Heston et al., 2007). For variable definitions, please see the Data Appendix. 
Table 2: Sample Descriptive Statistics

\begin{tabular}{|c|c|c|c|c|c|c|c|c|c|c|c|c|c|}
\hline Variables/Country & USA & Sweden & Denmark & Germany I & Netherlands & Belgium & France & Switzerland & Austria & Italy & Spain & Greece & England \\
\hline Age & 64.3 & 67.1 & 65.5 & 66.0 & 65.5 & 66.5 & 66.7 & 65.0 & 66.3 & 66.7 & 67.2 & 66.8 & 67.2 \\
\hline Household size & 2.18 & 1.79 & 1.76 & 1.87 & 1.95 & 2.02 & 2.03 & 1.93 & 1.84 & 2.37 & 2.49 & 2.15 & 1.38 \\
\hline $\begin{array}{l}\text { High School } \\
\text { Education }\end{array}$ & 0.57 & 0.27 & 0.40 & 0.55 & 0.25 & 0.27 & 0.31 & 0.44 & 0.48 & 0.22 & 0.09 & 0.24 & 0.22 \\
\hline College Education & 0.28 & 0.26 & 0.40 & 0.30 & 0.25 & 0.31 & 0.23 & 0.12 & 0.27 & 0.08 & 0.14 & 0.16 & 0.15 \\
\hline Recall Score & 5.90 & 4.20 & 4.48 & 3.98 & 4.07 & 3.69 & 3.41 & 4.58 & 3.81 & 2.93 & 2.70 & 3.56 & 5.92 \\
\hline $\begin{array}{l}\text { Self Reported Health } \\
\text { Fair or Bad }\end{array}$ & 0.35 & 0.23 & 0.37 & 0.53 & 0.41 & 0.42 & 0.47 & 0.28 & 0.40 & 0.59 & 0.56 & 0.41 & 0.36 \\
\hline Number of ADL's & 0.40 & 0.83 & 0.34 & 0.34 & 0.52 & 0.62 & 0.51 & 0.21 & 0.61 & 0.61 & 0.59 & 0.30 & 1.57 \\
\hline Retired & 0.41 & 0.50 & 0.50 & 0.54 & 0.43 & 0.57 & 0.56 & 0.44 & 0.63 & 0.57 & 0.43 & 0.50 & 0.55 \\
\hline Working & 0.51 & 0.47 & 0.44 & 0.37 & 0.40 & 0.31 & 0.35 & 0.50 & 0.29 & 0.29 & 0.35 & 0.34 & 0.34 \\
\hline Couple & 0.53 & 0.59 & 0.58 & 0.60 & 0.63 & 0.67 & 0.62 & 0.65 & 0.53 & 0.62 & 0.62 & 0.60 & 0.55 \\
\hline Widow & 0.23 & 0.19 & 0.21 & 0.22 & 0.21 & 0.20 & 0.22 & 0.19 & 0.27 & 0.24 & 0.25 & 0.28 & 0.26 \\
\hline Never Married & 0.05 & 0.08 & 0.07 & 0.08 & 0.07 & 0.04 & 0.07 & 0.06 & 0.09 & 0.10 & 0.09 & 0.06 & 0.07 \\
\hline $\begin{array}{l}\text { Expectation to Leave } \\
\text { a Bequest }\end{array}$ & 0.88 & 0.87 & 0.86 & 0.80 & 0.73 & 0.90 & 0.85 & 0.86 & 0.79 & 0.84 & 0.83 & 0.89 & 0.85 \\
\hline $\begin{array}{l}\text { Provides Help to } \\
\text { Others }\end{array}$ & 0.63 & 0.67 & 0.60 & 0.45 & 0.55 & 0.62 & 0.59 & 0.51 & 0.48 & 0.59 & 0.30 & 0.36 & 0.18 \\
\hline $\begin{array}{l}\text { Engages in } \\
\text { Voluntary Activities }\end{array}$ & 0.41 & 0.40 & 0.37 & 0.26 & 0.44 & 0.37 & 0.38 & 0.34 & 0.20 & 0.32 & 0.13 & 0.08 & 0.16 \\
\hline Household Income & $28,502.0$ & $31,617.6$ & $30,511.7$ & $27,020.2$ & 29,989.7 & $19,732.1$ & $25,862.9$ & 29,379.6 & $27,469.2$ & $19,197.1$ & $14,228.5$ & $13,698.4$ & $17,451.1$ \\
\hline Net Worth & $162,100.0$ & $90,586.1$ & $102,913.7$ & $95,418.1$ & $140,448.9$ & $199,399.8$ & $177,104.7$ & $198,392.6$ & $112,521.6$ & $149,455.6$ & $140,690.8$ & $111,671.4$ & $257,350.7$ \\
\hline
\end{tabular}

Note: All amounts are in thousands of PPP-adjusted dollars. PPP exchange rates are taken from the Penn World Tables, version 6.2 (Heston et al., 2007). For variable definitions, please see the Data Appendix. Averages are shown for age, household size, recall score, number of limitations in activities of daily living (ADLs), and expectation to leave a bequest, while medians for household income and net worth. The figures for the remaining variables denote prevalence, i.e. the fraction of households exhibiting the particular characteristic. 
Table 3a. Decompositions of Differences in Asset Ownership Rates between the US and Europe

\begin{tabular}{|c|c|c|c|c|c|c|c|c|c|c|c|c|}
\hline \multirow[b]{2}{*}{$\begin{array}{l}\text { Country/ } \\
\text { Region }\end{array}$} & \multicolumn{3}{|c|}{ Stocks } & \multicolumn{3}{|c|}{ Own Business } & \multicolumn{3}{|c|}{ Home } & \multicolumn{3}{|c|}{ Mortgage } \\
\hline & $\begin{array}{c}\text { Total } \\
\text { Difference }\end{array}$ & $\begin{array}{c}\text { Difference } \\
\text { due to } \\
\text { Coefficients }\end{array}$ & $\begin{array}{c}\text { Difference } \\
\text { due to } \\
\text { Covariates }\end{array}$ & $\begin{array}{c}\text { Total } \\
\text { Difference }\end{array}$ & $\begin{array}{c}\text { Difference } \\
\text { due to } \\
\text { Coefficients }\end{array}$ & $\begin{array}{c}\text { Difference } \\
\text { due to } \\
\text { Covariates }\end{array}$ & $\begin{array}{c}\text { Total } \\
\text { Difference }\end{array}$ & $\begin{array}{c}\text { Difference } \\
\text { due to } \\
\text { Coefficients }\end{array}$ & $\begin{array}{c}\text { Difference } \\
\text { due to } \\
\text { Covariates }\end{array}$ & $\begin{array}{c}\text { Total } \\
\text { Difference }\end{array}$ & $\begin{array}{c}\text { Difference } \\
\text { due to } \\
\text { Coefficients }\end{array}$ & $\begin{array}{c}\text { Difference } \\
\text { due to } \\
\text { Covariates }\end{array}$ \\
\hline Sweden & -0.211 & $-0.346 * * *$ & $0.135 * * *$ & -0.031 & $-0.061 * * *$ & $0.030 * * *$ & 0.083 & $0.066 * * *$ & $0.018 * * *$ & -0.019 & $-0.082 * * *$ & $0.062 * * *$ \\
\hline Denmark & -0.064 & $-0.132 * * *$ & $0.068 * * *$ & 0.003 & $-0.018 *$ & $0.020 * * *$ & 0.080 & $0.072 * * *$ & 0.008 & -0.060 & $-0.095 * * *$ & $0.035 * * *$ \\
\hline Germany & 0.243 & $0.133 * * *$ & $0.110 * * *$ & 0.033 & 0.010 & $0.024 * * *$ & 0.260 & $0.195 * * *$ & $0.066 * * *$ & 0.234 & $0.146 * * *$ & $0.088 * * *$ \\
\hline Netherlands & 0.248 & $0.112 * * *$ & $0.136 * * *$ & 0.029 & 0.008 & $0.021 * * *$ & 0.221 & $0.149 * * *$ & $0.071 * * *$ & -0.049 & $-0.112 * * *$ & $0.063 * * *$ \\
\hline Belgium & 0.120 & $0.047 * * *$ & $0.073 * * *$ & 0.044 & $0.055 * * *$ & $-0.011 * *$ & -0.027 & $-0.038 * * *$ & 0.011 & 0.264 & $0.218 * * *$ & $0.046 * * *$ \\
\hline France & 0.067 & $-0.041 * * *$ & $0.108 * * *$ & 0.038 & $0.025 * * *$ & $0.013 * * *$ & 0.051 & 0.003 & $0.048 * * *$ & 0.264 & $0.200 * * *$ & $0.063 * * *$ \\
\hline Switzerland & 0.134 & $0.048 * *$ & $0.086 * * *$ & -0.011 & -0.014 & 0.003 & 0.225 & $0.230 * * *$ & -0.005 & -0.070 & $-0.110 * * *$ & $0.040 * * *$ \\
\hline Austria & 0.395 & $0.266 * * *$ & $0.128 * * *$ & 0.057 & $0.031 * * *$ & $0.026 * * *$ & 0.205 & $0.127 * * *$ & $0.078 * * *$ & 0.291 & $0.207 * * *$ & $0.084 * * *$ \\
\hline Italy & 0.393 & $0.169 * * *$ & $0.223 * * *$ & 0.033 & 0.011 & $0.022 * * *$ & 0.022 & $-0.034 * *$ & $0.056 * * *$ & 0.327 & $0.240 * * *$ & $0.088 * * *$ \\
\hline Spain & 0.369 & $0.104 * * *$ & $0.264 * * *$ & 0.031 & 0.008 & $0.023 * * *$ & -0.096 & $-0.183 * * *$ & $0.087 * * *$ & 0.286 & $0.221 * * *$ & $0.065 * * *$ \\
\hline Greece & 0.391 & $0.178 * * *$ & $0.213 * * *$ & 0.032 & $0.015 *$ & $0.017 * * *$ & -0.070 & $-0.094 * * *$ & $0.024 * * *$ & 0.328 & $0.257 * * *$ & $0.071 * * *$ \\
\hline England & 0.103 & $0.027 * *$ & $0.076 * * *$ & 0.073 & $0.072 * * *$ & 0.002 & 0.012 & $-0.042 * * *$ & $0.054 * * *$ & 0.215 & $0.150 * * *$ & $0.064 * * *$ \\
\hline
\end{tabular}

Note: All amounts are in thousands of PPP-adjusted dollars. PPP exchange rates are taken from the Penn World Tables, version 6.2 (Heston et al., 2007). For variable definitions, please see the Data Appendix. All decompositions differences calculated with respect to the US. ***, **, * denote significance at $1 \%$, 5\% and 10\%, respectively. Standard errors have been computed using 200 bootstrap replications. 
Table 3b: Decompositions of Differences in Asset Ownership Rates within the US and Europe

\begin{tabular}{|c|c|c|c|c|c|c|c|c|c|c|c|c|}
\hline \multirow[b]{2}{*}{$\begin{array}{l}\text { Country/ } \\
\text { Region }\end{array}$} & \multicolumn{3}{|c|}{ Stocks } & \multicolumn{3}{|c|}{ Own Business } & \multicolumn{3}{|c|}{ Home } & \multicolumn{3}{|c|}{ Mortgage } \\
\hline & $\begin{array}{c}\text { Total } \\
\text { Difference }\end{array}$ & $\begin{array}{c}\text { Difference } \\
\text { due to } \\
\text { Coefficients }\end{array}$ & $\begin{array}{c}\text { Difference } \\
\text { due to } \\
\text { Covariates }\end{array}$ & $\begin{array}{c}\text { Total } \\
\text { Difference }\end{array}$ & $\begin{array}{c}\text { Difference } \\
\text { due to } \\
\text { Coefficients }\end{array}$ & $\begin{array}{c}\text { Difference } \\
\text { due to } \\
\text { Covariates }\end{array}$ & $\begin{array}{c}\text { Total } \\
\text { Difference }\end{array}$ & $\begin{array}{c}\text { Difference } \\
\text { due to } \\
\text { Coefficients }\end{array}$ & $\begin{array}{c}\text { Difference } \\
\text { due to } \\
\text { Covariates }\end{array}$ & $\begin{array}{c}\text { Total } \\
\text { Difference }\end{array}$ & $\begin{array}{c}\text { Difference } \\
\text { due to } \\
\text { Coefficients }\end{array}$ & $\begin{array}{c}\text { Difference } \\
\text { due to } \\
\text { Covariates }\end{array}$ \\
\hline US Northeast & -0.002 & $-0.023 * * *$ & $0.021 * * *$ & 0.070 & $0.057 * * *$ & $0.014 * * *$ & 0.102 & $0.063 * * *$ & $0.039 * * *$ & 0.069 & $0.054 *$ & $0.014 *$ \\
\hline US South & 0.119 & $0.040 * * *$ & $0.079 * * *$ & 0.045 & $0.023 * * *$ & $0.023 * * *$ & 0.025 & $-0.030 * * *$ & $0.055 * * *$ & 0.028 & 0.019 & 0.009 \\
\hline US West & 0.025 & $0.045 * * *$ & $-0.020 * * *$ & 0.053 & 0.052 & 0.001 & 0.041 & $0.023 * * *$ & $0.018 * * *$ & -0.065 & -0.053 & -0.012 \\
\hline Sweden & -0.454 & $-0.454 * * *$ & 0.000 & -0.064 & $-0.077 * * *$ & $0.012 * *$ & -0.177 & $-0.173 * * *$ & -0.004 & -0.254 & $-0.216 * * *$ & $-0.038 * *$ \\
\hline Denmark & -0.307 & $-0.271 * * *$ & $-0.035 * * *$ & -0.031 & $-0.028 * *$ & -0.003 & -0.180 & $-0.136 * * *$ & $-0.044 * * *$ & -0.294 & $-0.257 * * *$ & $-0.038 * * *$ \\
\hline Netherlands & 0.005 & 0.019 & -0.014 & -0.005 & -0.003 & -0.001 & -0.040 & $-0.092 * * *$ & $0.052 * * *$ & -0.283 & $-0.241 * * *$ & $-0.042 * * *$ \\
\hline Belgium & -0.122 & $-0.080 * * *$ & $-0.042 * * *$ & 0.010 & $0.018 *$ & -0.007 & -0.288 & $-0.263 * * *$ & -0.025 & 0.029 & $0.080 * * *$ & $-0.050 * * *$ \\
\hline France & -0.176 & $-0.160 * * *$ & -0.015 & 0.005 & 0.005 & -0.001 & -0.210 & $-0.221 * * *$ & 0.011 & 0.029 & $0.073 * * *$ & $-0.044 * * *$ \\
\hline Switzerland & -0.109 & $-0.067 * *$ & $-0.043 * *$ & -0.045 & $-0.037 * *$ & -0.008 & -0.036 & -0.009 & -0.026 & -0.304 & $-0.266 * * *$ & $-0.039 * *$ \\
\hline Austria & 0.152 & $0.146 * * *$ & 0.006 & 0.023 & $0.026 * * *$ & -0.003 & -0.055 & $-0.101 * * *$ & $0.046 * * *$ & 0.057 & $0.064 * * *$ & -0.007 \\
\hline Italy & 0.150 & $0.115 * * *$ & 0.035 & -0.001 & -0.019 & $0.019 * *$ & -0.239 & $-0.279 * * *$ & 0.040 & 0.093 & $0.123 * * *$ & -0.030 \\
\hline Spain & 0.126 & $0.080 * * *$ & $0.046 *$ & -0.003 & $-0.026 * *$ & $0.023 * *$ & -0.357 & $-0.422 * * *$ & $0.066 * *$ & 0.051 & $0.071 * *$ & -0.020 \\
\hline Greece & 0.149 & $0.124 * * *$ & 0.025 & -0.002 & -0.016 & $0.014 *$ & -0.331 & $-0.363 * * *$ & 0.032 & 0.093 & $0.096 * * *$ & -0.003 \\
\hline England & -0.140 & $-0.081 * *$ & $-0.059 *$ & 0.040 & $0.030 * * *$ & 0.010 & -0.248 & $-0.333 * * *$ & $0.084 * * *$ & -0.020 & -0.010 & -0.010 \\
\hline
\end{tabular}

Note: All amounts are in thousands of PPP-adjusted dollars. PPP exchange rates are taken from the Penn World Tables, version 6.2 (Heston et al., 2007). For variable definitions, please see the Data Appendix. All decompositions differences calculated with respect to the US. $* * *, * *, *$ denote significance at $1 \%$, $5 \%$ and $10 \%$, respectively. Standard errors have been computed using 200 bootstrap replications. 
Table 4: Selected Aggregate Indicators

\begin{tabular}{|c|c|c|c|c|c|c|c|c|c|c|}
\hline & \multicolumn{4}{|c|}{ Stockholding } & \multicolumn{4}{|c|}{ Business } & \multicolumn{2}{|c|}{ Housing } \\
\hline Country & $\begin{array}{c}\text { Market } \\
\text { Cap to } \\
\text { GDP } \\
\text { Ratio }\end{array}$ & $\begin{array}{l}\text { Antidirector } \\
\text { Rights } \\
\text { Index }\end{array}$ & $\begin{array}{c}\text { Internet } \\
\text { Connections } \\
\text { (per } \\
\text { thousand) }\end{array}$ & $\begin{array}{c}\text { Country } \\
\text { Index of } \\
\text { Interpersonal } \\
\text { Trust }\end{array}$ & $\begin{array}{c}\text { Ease of } \\
\text { Doing } \\
\text { Business } \\
\text { (rank) }\end{array}$ & $\begin{array}{l}\text { Getting } \\
\text { Credit } \\
\text { (rank) }\end{array}$ & $\begin{array}{c}\text { Paying } \\
\text { Taxes } \\
\text { (rank) }\end{array}$ & $\begin{array}{c}\text { Trading } \\
\text { Across } \\
\text { Borders } \\
\text { (rank) }\end{array}$ & $\begin{array}{l}\text { Harmonised } \\
\text { Index of } \\
\text { Housing } \\
\text { Prices }\end{array}$ & $\begin{array}{c}\text { VAT } \\
\text { on New } \\
\text { Homes } \\
(\%)\end{array}$ \\
\hline Austria & 29.6 & 4 & 486 & 70.2 & 30 & 19 & 102 & 13 & 119.5 & $10-20$ \\
\hline Belgium & 219.6 & 2 & 458 & 63.0 & 20 & 41 & 62 & 38 & 120.8 & 21 \\
\hline Denmark & 62.3 & 4 & 527 & 131.9 & 7 & 19 & 19 & 3 & 129.2 & 25 \\
\hline France & 92.7 & 5 & 430 & 37.9 & 47 & 96 & 92 & 81 & 113.0 & 19.6 \\
\hline Germany & 44.0 & 4 & 455 & 75.8 & 21 & 3 & 70 & 6 & 117.3 & 16 \\
\hline Greece & 61.6 & 3 & 180 & 54.6 & 111 & 76 & 100 & 119 & 132.2 & $11-13$ \\
\hline Italy & 47.2 & 4 & 478 & 60.8 & 69 & 41 & 112 & 103 & 125.1 & 4 \\
\hline Netherlands & 107.8 & 4 & 739 & 90.6 & 22 & 13 & 81 & 16 & 139.9 & 19 \\
\hline Spain & 94.9 & 6 & 348 & 40.9 & 38 & 19 & 103 & 24 & 125.2 & 7 \\
\hline Sweden & 108.8 & 4 & 764 & 134.5 & 14 & 33 & 37 & 9 & 126.4 & 25 \\
\hline Switzerland & 229.7 & 3 & 498 & 107.4 & 16 & 19 & 7 & 47 & n.a & n.a. \\
\hline UK & 131.5 & 5 & 473 & 61.7 & 5 & 1 & 11 & 14 & 118.2 & 0 \\
\hline USA & 139.9 & 2 & 630 & 78.8 & 3 & 7 & 55 & 10 & n.a & 0 \\
\hline
\end{tabular}

Note: Stockholding: Market Cap to GDP Ratio (\%): the ratio of market capitalization to GDP (Source: World Development Indicators). Antidirector rights index: revised version for 2005 by Spamann (2009) of the originally computed index by La Porta et al. (1998) that aggregates the shareholder rights (more details are provided in Table A1 of the Web Appendix). The country index of interpersonal trust is from the ASEP/ JDS Databank. Business: World Bank, Doing Business (http://www.doingbusiness.org), rankings for 2005. The ease of doing business index is calculated as the ranking on the simple average of country percentile rankings on each of the 10 topics covered in Doing Business (more details are provided in Table A2 of the Web Appendix). The ranking on each topic is the simple average of the percentile rankings on its component indicators. Getting credit: Strength of legal rights index, depth of credit information index. Paying taxes: Number of tax payments, time to prepare tax returns and total taxes as a share of commercial profits. Trading across borders: Documents, time and cost to export and import. House: Indicators are from Housing Statistics in the European Union for 2004 (National Board of Housing, Building and Planning, Sweden). 
Table 5: Coefficient Effects Related to Selected Economic Indicators (ownership)

\begin{tabular}{lrl}
\hline Indicator & $\begin{array}{c}\text { Differences due to Coefficients } \\
\text { Coefficient }\end{array}$ Std. Error \\
\hline \multicolumn{3}{c}{ Panel A. Stocks } \\
Market capitalization to GDP ratio & -0.0008 & 0.0007 \\
Internet Connections & 0.0000 & 0.0004 \\
Antidirector Rights Index & -0.0566 & $0.0251 * *$ \\
Country Index of Interpersonal Trust & -0.0035 & $0.0020^{*}$ \\
$R 2$ & 0.55 & \\
\hline
\end{tabular}

Panel B. Own Business

\begin{tabular}{lrl} 
Tax Burden & 0.0003 & 0.0001 \\
Difficulty in Getting Credit & 0.0003 & 0.0001 \\
Difficulty in Trading Across Borders & -0.0002 & 0.0001 \\
$R 2$ & 0.53 & \\
\hline
\end{tabular}

Panel C. Home

\begin{tabular}{lcl} 
Housing Price Index (harmonized) & -0.0004 & 0.0051 \\
VAT on New Homes & 0.0065 & 0.0027 \\
$R 2$ & 0.26 & \\
\hline
\end{tabular}

Note: Robust regression estimates of estimated differences in ownership rates due to coefficients on various indicators. $* * *, * *, *$ denote significance at $1 \%, 5 \%$ and $10 \%$, respectively. Tax burden/ difficulty in getting credit/ difficulty in trading 
Table 6a: Decomposition of Differences in Holdings between the US and Europe, Owners Only

\begin{tabular}{|c|c|c|c|c|c|c|c|c|c|}
\hline \multirow[b]{2}{*}{ Country } & \multicolumn{3}{|c|}{ 25th Quantile } & \multicolumn{3}{|c|}{ 50th Quantile } & \multicolumn{3}{|c|}{ 75th Quantile } \\
\hline & $\begin{array}{c}\text { Total } \\
\text { Difference }\end{array}$ & $\begin{array}{c}\text { Difference } \\
\text { due to } \\
\text { Coefficients }\end{array}$ & $\begin{array}{l}\text { Difference } \\
\text { due to } \\
\text { Covariates } \\
\end{array}$ & $\begin{array}{c}\text { Total } \\
\text { Difference }\end{array}$ & $\begin{array}{c}\text { Difference } \\
\text { due to } \\
\text { Coefficients }\end{array}$ & $\begin{array}{c}\text { Difference } \\
\text { due to } \\
\text { Covariates } \\
\end{array}$ & $\begin{array}{c}\text { Total } \\
\text { Difference }\end{array}$ & $\begin{array}{c}\text { Difference } \\
\text { due to } \\
\text { Coefficients } \\
\end{array}$ & $\begin{array}{c}\text { Difference } \\
\text { due to } \\
\text { Covariates } \\
\end{array}$ \\
\hline \multicolumn{10}{|c|}{ Panel A. Stocks } \\
\hline Sweden & 1.024 & $0.185 * * *$ & $0.839 * * *$ & 1.407 & $0.428 * * *$ & $0.979 * * *$ & 1.625 & $0.748 * * *$ & $0.877 * * *$ \\
\hline Denmark & 1.407 & $0.974 * * *$ & $0.432 * * *$ & 1.788 & $1.233 * * *$ & $0.555 * * *$ & 2.008 & $1.528 * * *$ & $0.480 * * *$ \\
\hline Germany & 1.138 & $0.982 * * *$ & $0.156 * *$ & 1.657 & $1.339 * * *$ & $0.318 * * *$ & 1.864 & $1.570 * * *$ & $0.294 * * *$ \\
\hline Netherlands & 0.882 & $0.681 * * *$ & $0.201 * * *$ & 1.182 & $0.896 * * *$ & $0.286 * * *$ & 1.391 & $1.143 * * *$ & $0.248 * * *$ \\
\hline Belgium & 0.761 & $0.671 * * *$ & 0.090 & 0.887 & $0.659 * * *$ & $0.228 * * *$ & 0.887 & $0.677 * * *$ & $0.210 * * *$ \\
\hline France & 1.406 & $1.090 * * *$ & $0.316 * * *$ & 1.758 & $1.297 * * *$ & $0.460 * * *$ & 1.848 & $1.439 * * *$ & $0.409 * * *$ \\
\hline Switzerland & 0.421 & 0.148 & $0.273 * * *$ & 0.663 & $0.238 * *$ & $0.425 * * *$ & 0.638 & 0.240 & $0.398 * * *$ \\
\hline Austria & 1.293 & $1.508 * * *$ & $-0.215 * * *$ & 1.810 & $1.846 * * *$ & -0.036 & 1.818 & $1.801 * * *$ & 0.016 \\
\hline Italy & 0.845 & $0.574 * * *$ & $0.271 * * *$ & 1.253 & $0.800 * * *$ & $0.453 * * *$ & 1.543 & $1.132 * * *$ & $0.411 * * *$ \\
\hline Spain & 1.026 & $0.504 * * *$ & $0.523 * * *$ & 1.506 & $0.890 * * *$ & $0.616 * * *$ & 1.923 & $1.411 * * *$ & $0.511 * * *$ \\
\hline Greece & 2.288 & $1.935 * * *$ & $0.353 * * *$ & 2.365 & $1.891 * * *$ & $0.474 * * *$ & 2.612 & $2.229 * * *$ & $0.383 * * *$ \\
\hline England & 0.873 & $0.851 * * *$ & 0.022 & 1.153 & $1.025 * * *$ & $0.128 * * *$ & 1.177 & $1.082 * * *$ & $0.096 * *$ \\
\hline \multicolumn{10}{|c|}{ Panel B. Own Business } \\
\hline Sweden & -0.596 & $-0.877 * * *$ & 0.281 & -1.233 & $-1.445 * * *$ & $0.212 * *$ & -0.987 & $-1.428 * * *$ & $0.441 * * *$ \\
\hline Denmark & -0.747 & $-1.084 * * *$ & $0.337 *$ & -1.217 & $-1.370 * * *$ & 0.153 & -1.574 & $-1.877 * * *$ & $0.303 * * *$ \\
\hline Germany & 0.646 & 0.371 & 0.275 & 0.646 & $0.501 * * *$ & 0.145 & 0.836 & $0.489 * * *$ & $0.347 * * *$ \\
\hline Netherlands & 0.787 & $0.620 * * *$ & 0.167 & 0.276 & 0.308 & -0.032 & -0.369 & -0.623 & $0.254 * *$ \\
\hline Belgium & -0.465 & $-0.341 * * *$ & -0.124 & -0.251 & -0.048 & $-0.203 * *$ & 0.127 & 0.040 & 0.087 \\
\hline France & 1.405 & $1.280 * * *$ & 0.125 & 0.484 & 0.458 & 0.025 & 0.517 & 0.231 & $0.285 * *$ \\
\hline Switzerland & -0.312 & $-0.336 * *$ & 0.024 & -0.158 & -0.118 & -0.039 & -0.006 & -0.126 & 0.121 \\
\hline Austria & -0.138 & -0.531 & $0.394 * *$ & 0.211 & -0.071 & $0.281 * * *$ & 0.483 & -0.062 & $0.545 * * *$ \\
\hline Italy & 0.956 & $0.866 * * *$ & 0.089 & 0.540 & $0.448 * * *$ & 0.092 & 1.070 & $0.640 * * *$ & $0.431 * * *$ \\
\hline Spain & 0.281 & 0.094 & 0.187 & 0.551 & $0.397 * * *$ & 0.154 & 1.095 & $0.658 * * *$ & $0.437 * * *$ \\
\hline Greece & 0.072 & $-0.548 * * *$ & $0.620 * * *$ & 0.072 & $-0.389 *$ & $0.461 * * *$ & -0.224 & $-0.971 * * *$ & $0.747 * * *$ \\
\hline England & 1.876 & $2.154 * * *$ & -0.278 & 0.960 & $1.433 * * *$ & $-0.474 * * *$ & 0.267 & $0.591 *$ & $-0.324 * * *$ \\
\hline \multicolumn{10}{|c|}{ Panel C. Home } \\
\hline Sweden & 0.447 & $0.178 * * *$ & $0.269 * * *$ & 0.488 & $0.162 * * *$ & $0.326 * * *$ & 0.488 & $0.227 * * *$ & $0.261 * * *$ \\
\hline Denmark & -0.126 & $-0.264 * * *$ & $0.138 * * *$ & 0.097 & $-0.085 * *$ & $0.182 * * *$ & 0.202 & $0.089 *$ & $0.114 * * *$ \\
\hline Germany & -0.533 & $-0.741 * * *$ & $0.208 * * *$ & -0.335 & $-0.603 * * *$ & $0.268 * * *$ & -0.230 & $-0.432 * * *$ & $0.202 * * *$ \\
\hline Netherlands & -0.877 & $-1.084 * * *$ & $0.207 * * *$ & -0.523 & $-0.776 * * *$ & $0.253 * * *$ & -0.404 & $-0.591 * * *$ & $0.187 * * *$ \\
\hline Belgium & -0.465 & $-0.833 * * *$ & $0.368 * * *$ & -0.146 & $-0.538 * * *$ & $0.392 * * *$ & -0.019 & $-0.324 * * *$ & $0.305 * * *$ \\
\hline France & -0.439 & $-0.827 * * *$ & $0.388 * * *$ & -0.216 & $-0.642 * * *$ & $0.426 * * *$ & -0.216 & $-0.567 * * *$ & $0.351 * * *$ \\
\hline Switzerland & -1.054 & $-1.196 * * *$ & $0.142 * * *$ & -0.750 & $-0.943 * * *$ & $0.193 * * *$ & -0.608 & $-0.738 * * *$ & $0.130 * * *$ \\
\hline Austria & -0.300 & $-0.651 * * *$ & $0.351 * * *$ & -0.077 & $-0.470 * * *$ & $0.393 * * *$ & -0.077 & $-0.417 * * *$ & $0.340 * * *$ \\
\hline Italy & -0.176 & $-0.834 * * *$ & $0.657 * * *$ & -0.118 & $-0.799 * * *$ & $0.681 * * *$ & -0.118 & $-0.713 * * *$ & $0.596 * * *$ \\
\hline Spain & -0.050 & $-0.815 * * *$ & $0.766 * * *$ & 0.133 & $-0.605 * * *$ & $0.739 * * *$ & 0.129 & $-0.476 * * *$ & $0.605 * * *$ \\
\hline Greece & 0.254 & $-0.345 * * *$ & $0.599 * * *$ & 0.451 & $-0.141 * * *$ & $0.592 * * *$ & 0.518 & $0.048 * *$ & $0.470 * * *$ \\
\hline England & -0.873 & $-1.260 * * *$ & $0.387 * * *$ & -0.609 & $-1.044 * * *$ & $0.436 * * *$ & -0.466 & $-0.825 * * *$ & $0.360 * * *$ \\
\hline \multicolumn{10}{|c|}{ Panel D. Mortgages } \\
\hline Sweden & 0.746 & $0.440 * * *$ & $0.306 * * *$ & 0.824 & $0.519 * * *$ & $0.306 * * *$ & 0.785 & $0.495 * * *$ & $0.291 * * *$ \\
\hline Denmark & 0.121 & -0.049 & $0.170 * * *$ & 0.210 & 0.027 & $0.183 * * *$ & 0.320 & $0.140 * * *$ & $0.180 * * *$ \\
\hline Germany & 0.933 & $0.918 * * *$ & 0.016 & 0.646 & $0.569 * * *$ & $0.077 * * *$ & 0.406 & $0.312 * * *$ & $0.094 * * *$ \\
\hline Netherlands & 0.296 & $0.351 * * *$ & -0.055 & 0.248 & $0.253 * * *$ & -0.006 & 0.124 & $0.119 * * *$ & 0.004 \\
\hline Belgium & 1.821 & $1.874 * * *$ & -0.053 & 1.580 & $1.564 * * *$ & 0.015 & 1.342 & $1.290 * * *$ & $0.053 *$ \\
\hline France & 1.404 & $1.303 * * *$ & $0.101 * *$ & 1.085 & $0.933 * * *$ & $0.152 * * *$ & 0.882 & $0.696 * * *$ & $0.186 * * *$ \\
\hline Switzerland & -0.466 & $-0.427 * * *$ & -0.040 & -0.401 & $-0.381 * * *$ & -0.020 & -0.477 & $-0.456 * * *$ & -0.020 \\
\hline Austria & 2.812 & $2.777 * * *$ & 0.035 & 1.869 & $1.778 * * *$ & $0.091 * * *$ & 1.063 & $0.933 * * *$ & $0.130 * * *$ \\
\hline Italy & 1.208 & $0.981 * * *$ & $0.228 * * *$ & 0.953 & $0.718 * * *$ & $0.235 * * *$ & 0.799 & $0.580 * * *$ & $0.219 * * *$ \\
\hline Spain & 1.213 & $0.916 * * *$ & $0.297 * * *$ & 0.842 & $0.593 * * *$ & $0.249 * * *$ & 0.758 & $0.530 * * *$ & $0.228 * * *$ \\
\hline Greece & 1.864 & $1.716 * * *$ & $0.148 * * *$ & 1.325 & $1.136 * * *$ & $0.189 * * *$ & 1.211 & $0.997 * * *$ & $0.215 * * *$ \\
\hline England & 1.093 & $1.148 * * *$ & -0.055 & 0.932 & $0.930 * * *$ & 0.002 & 0.681 & $0.650 * * *$ & 0.031 \\
\hline
\end{tabular}

Note: All amounts: thousands of PPP-adjusted dollars. For variable definitions, see Data Appendix. All differences calculated relative to the US. ${ }^{* *},{ }^{* *},{ }^{*}$ denote significance at $1 \%, 5 \%$ and $10 \%$, respectively. Standard errors computed using 100 bootstrap replications. 
Table 6b: Decomposition of Differences in Holdings within the US and Europe, Owners Only

\begin{tabular}{|c|c|c|c|c|c|c|c|c|c|}
\hline \multirow[b]{2}{*}{$\begin{array}{c}\text { Country/ } \\
\text { Region }\end{array}$} & \multicolumn{3}{|c|}{ 25th Quantile } & \multicolumn{3}{|c|}{ 50th Quantile } & \multicolumn{3}{|c|}{ 75th Quantile } \\
\hline & $\begin{array}{c}\text { Total } \\
\text { Difference }\end{array}$ & $\begin{array}{c}\text { Difference } \\
\text { due to } \\
\text { Coefficients }\end{array}$ & $\begin{array}{c}\text { Difference } \\
\text { due to } \\
\text { Covariates }\end{array}$ & $\begin{array}{c}\text { Total } \\
\text { Difference }\end{array}$ & $\begin{array}{c}\text { Difference } \\
\text { due to } \\
\text { Coefficients }\end{array}$ & $\begin{array}{c}\text { Difference } \\
\text { due to } \\
\text { Covariates }\end{array}$ & $\begin{array}{c}\text { Total } \\
\text { Difference }\end{array}$ & $\begin{array}{c}\text { Difference } \\
\text { due to } \\
\text { Coefficients }\end{array}$ & $\begin{array}{c}\text { Difference } \\
\text { due to } \\
\text { Covariates }\end{array}$ \\
\hline \multicolumn{10}{|c|}{ Panel A. Stocks } \\
\hline $\begin{array}{l}\text { US Northeast } \\
\text { US South } \\
\text { US West }\end{array}$ & $\begin{array}{c}-0.095 \\
0.000 \\
-0.337\end{array}$ & $\begin{array}{l}0.048 \\
0.082 \\
0.038\end{array}$ & $\begin{array}{l}-0.143 * \\
-0.082 \\
-0.375 * * *\end{array}$ & $\begin{array}{c}-0.145 \\
0.025 \\
-0.168\end{array}$ & $\begin{array}{l}-0.022 \\
0.052 \\
0.186 \text { *** }\end{array}$ & $\begin{array}{l}-0.122 * \\
-0.027 \\
-0.354 * * *\end{array}$ & $\begin{array}{l}-0.139 \\
-0.019 \\
-0.195\end{array}$ & $\begin{array}{l}0.039 \\
0.095 \\
0.184 * *\end{array}$ & $\begin{array}{l}-0.178 * \\
-0.114 \\
-0.379 * * *\end{array}$ \\
\hline Sweden & -0.114 & $-0.719 * * *$ & $0.604 * * *$ & -0.251 & $-0.791 * * *$ & $0.540 * * *$ & -0.239 & $-0.810 * * *$ & $0.572 * * *$ \\
\hline Denmark & 0.269 & 0.035 & $0.233 * *$ & 0.131 & -0.048 & $0.178 *$ & 0.144 & -0.032 & $0.176 *$ \\
\hline Netherlands & -0.256 & $-0.430 * * *$ & $0.174 *$ & -0.475 & $-0.493 * * *$ & 0.018 & -0.473 & $-0.522 * * *$ & 0.049 \\
\hline Belgium & -0.377 & $-0.442 * * *$ & 0.066 & -0.770 & $-0.745 * * *$ & -0.025 & -0.976 & $-1.006 * * *$ & 0.030 \\
\hline France & 0.268 & 0.006 & $0.262 * * *$ & 0.100 & $-0.137 * *$ & $0.238 * *$ & -0.016 & $-0.285 * * *$ & $0.269 * * *$ \\
\hline Switzerland & -0.717 & $-0.766 * * *$ & 0.049 & -0.994 & $-1.025 * * *$ & 0.031 & -1.225 & $-1.376 * * *$ & 0.151 \\
\hline Austria & 0.155 & 0.329 & $-0.174 *$ & 0.153 & 0.383 & $-0.230 * *$ & -0.046 & 0.104 & -0.150 \\
\hline Italy & -0.293 & $-0.517 * * *$ & $0.225 * *$ & -0.404 & $-0.580 * * *$ & $0.175 *$ & -0.320 & $-0.559 * * *$ & $0.239 * * *$ \\
\hline Spain & -0.112 & $-0.429 * * *$ & $0.317 * * *$ & -0.152 & $-0.359 * * *$ & $0.207 * *$ & 0.059 & $-0.212 *$ & $0.271 * * *$ \\
\hline Greece & 1.150 & $1.020 * * *$ & 0.129 & 0.707 & $0.614 * * *$ & 0.094 & 0.748 & $0.580 * * *$ & $0.168 *$ \\
\hline England & -0.265 & $-0.302 * * *$ & 0.037 & -0.504 & $-0.339 * * *$ & $-0.165 *$ & -0.687 & $-0.564 * * *$ & -0.123 \\
\hline \multicolumn{10}{|c|}{ Panel B. Own Business } \\
\hline US Northeast & 0.223 & 0.309 & -0.086 & 0.406 & $0.460 * * *$ & -0.054 & 0.288 & 0.341 & -0.053 \\
\hline US South & 0.693 & $0.798 * * *$ & -0.105 & 0.511 & $0.514 * * *$ & -0.003 & 0.470 & $0.420 * * *$ & 0.050 \\
\hline US West & 0.511 & $0.653 * *$ & -0.142 & 0.406 & $0.461 * *$ & -0.056 & 0.288 & 0.325 & -0.037 \\
\hline Sweden & -1.242 & $-1.067 * * *$ & -0.174 & -1.879 & $-1.669 * * *$ & $-0.210 *$ & -1.823 & $-1.705 * * *$ & -0.118 \\
\hline Denmark & -1.393 & $-1.416 * * *$ & 0.023 & -1.863 & $-1.731 * * *$ & -0.132 & -2.410 & $-2.417 * * *$ & 0.007 \\
\hline Netherlands & 0.141 & 0.109 & 0.032 & -0.370 & -0.261 & -0.109 & -1.205 & $-1.098 * *$ & -0.107 \\
\hline Belgium & -1.111 & $-1.016 * * *$ & -0.095 & -0.896 & $-0.737 * * *$ & -0.159 & -0.709 & $-0.609 * * *$ & -0.101 \\
\hline France & 0.759 & $0.572 *$ & 0.188 & -0.162 & -0.181 & 0.019 & -0.319 & $-0.417 * *$ & 0.097 \\
\hline Switzerland & -0.957 & $-1.100 * * *$ & 0.142 & -0.803 & $-0.737 * * *$ & -0.066 & -0.842 & $-0.845 * *$ & 0.003 \\
\hline Austria & -0.783 & $-0.768 * *$ & -0.016 & -0.435 & -0.177 & $-0.258 * *$ & -0.353 & -0.092 & -0.261 \\
\hline Italy & 0.310 & 0.305 & 0.005 & -0.106 & -0.085 & -0.021 & 0.234 & 0.229 & 0.005 \\
\hline Spain & -0.365 & $-0.591 * * *$ & 0.226 & -0.095 & $-0.310 * * *$ & 0.215 * & 0.259 & -0.195 & 0.453 ** \\
\hline Greece & -0.574 & $-0.764 * * *$ & 0.190 & -0.574 & $-0.739 * * *$ & 0.165 & -1.060 & $-1.427 * * *$ & $0.367 * *$ \\
\hline England & 1.230 & $1.844 * * *$ & $-0.614 * *$ & 0.314 & $0.914 * * *$ & $-0.600 * * *$ & -0.569 & -0.224 & $-0.345 *$ \\
\hline
\end{tabular}

(contd.) 
Table 6b: Decomposition of Differences in Holdings within the US and Europe, Owners Only (contd.)

\begin{tabular}{|c|c|c|c|c|c|c|c|c|c|}
\hline \multirow[b]{2}{*}{$\begin{array}{l}\text { Country/ } \\
\text { Region }\end{array}$} & \multicolumn{3}{|c|}{ 25th Quantile } & \multicolumn{3}{|c|}{ 50th Quantile } & \multicolumn{3}{|c|}{ 75th Quantile } \\
\hline & $\begin{array}{c}\text { Total } \\
\text { Difference }\end{array}$ & $\begin{array}{c}\text { Difference } \\
\text { due to } \\
\text { Coefficients }\end{array}$ & $\begin{array}{c}\text { Difference } \\
\text { due to } \\
\text { Covariates }\end{array}$ & $\begin{array}{c}\text { Total } \\
\text { Difference }\end{array}$ & $\begin{array}{c}\text { Difference } \\
\text { due to } \\
\text { Coefficients }\end{array}$ & $\begin{array}{c}\text { Difference } \\
\text { due to } \\
\text { Covariates }\end{array}$ & $\begin{array}{c}\text { Total } \\
\text { Difference }\end{array}$ & $\begin{array}{c}\text { Difference } \\
\text { due to } \\
\text { Coefficients }\end{array}$ & $\begin{array}{c}\text { Difference } \\
\text { due to } \\
\text { Covariates }\end{array}$ \\
\hline \multicolumn{10}{|c|}{ Panel C. Home } \\
\hline US Northeast & -0.115 & $-0.114 * * *$ & -0.001 & -0.364 & $-0.346 * * *$ & -0.019 & -0.531 & $-0.479 * * *$ & $-0.052 * *$ \\
\hline US South & 0.264 & $0.134 * * *$ & $0.129 * * *$ & 0.278 & $0.194 * * *$ & $0.084 * * *$ & 0.105 & $0.077 * * *$ & 0.029 \\
\hline US West & -0.535 & $-0.532 * * *$ & -0.003 & -0.639 & $-0.622 * * *$ & -0.016 & -0.693 & $-0.651 * * *$ & $-0.042 * *$ \\
\hline Sweden & 0.980 & $0.938 * * *$ & 0.042 & 0.823 & $0.776 * * *$ & 0.047 & 0.718 & $0.701 * * *$ & 0.017 \\
\hline Denmark & 0.407 & $0.372 * * *$ & 0.035 & 0.432 & $0.416 * * *$ & 0.016 & 0.432 & $0.413 * * *$ & 0.019 \\
\hline Netherlands & -0.344 & $-0.378 * * *$ & 0.034 & -0.188 & $-0.222 * * *$ & 0.035 & -0.174 & $-0.199 * * *$ & 0.024 \\
\hline Belgium & 0.068 & -0.027 & $0.095 *$ & 0.189 & $0.097 * *$ & $0.092 * * *$ & 0.211 & $0.143 * * *$ & $0.067 *$ \\
\hline France & 0.094 & -0.021 & $0.115 * *$ & 0.119 & 0.007 & $0.112 * * *$ & 0.014 & $-0.081 * * *$ & $0.095 * * *$ \\
\hline Switzerland & -0.521 & $-0.478 * * *$ & -0.043 & -0.414 & $-0.408 * * *$ & -0.006 & -0.378 & $-0.390 * * *$ & 0.012 \\
\hline Austria & 0.233 & $0.085 * * *$ & $0.148 * * *$ & 0.258 & $0.147 * * *$ & $0.112 * * *$ & 0.153 & $0.059 * * *$ & $0.094 * * *$ \\
\hline Italy & 0.357 & $0.159 *$ & $0.198 * * *$ & 0.217 & 0.002 & $0.215 * * *$ & 0.112 & $-0.062 * * *$ & $0.174 * * *$ \\
\hline Spain & 0.483 & $0.242 * * *$ & $0.241 * * *$ & 0.469 & $0.231 * * *$ & $0.237 * * *$ & 0.359 & $0.167 * * *$ & $0.192 * * *$ \\
\hline Greece & 0.787 & $0.592 * * *$ & $0.196 * * *$ & 0.786 & $0.588 * * *$ & $0.198 * * *$ & 0.748 & $0.600 * * *$ & $0.148 * * *$ \\
\hline England & -0.340 & $-0.410 * * *$ & 0.070 & -0.274 & $-0.360 * * *$ & $0.086 * * *$ & -0.236 & $-0.276 * * *$ & 0.040 \\
\hline \multicolumn{10}{|c|}{ Panel D. Mortgages } \\
\hline US Northeast & -0.065 & -0.025 & -0.040 & -0.074 & -0.022 & -0.052 & -0.166 & 0.002 & $-0.168 * * *$ \\
\hline US South & 0.051 & -0.039 & $0.090 *$ & 0.114 & 0.028 & 0.086 & 0.029 & 0.029 & 0.000 \\
\hline US West & -0.511 & $-0.431 * * *$ & -0.080 & -0.431 & $-0.337 * * *$ & $-0.094 *$ & -0.532 & $-0.339 * * *$ & $-0.193 * * *$ \\
\hline Sweden & -0.188 & $-0.493 * * *$ & $0.305 *$ & 0.179 & $-0.206 * * *$ & $0.384 * * *$ & 0.380 & -0.033 & $0.413 * * *$ \\
\hline Denmark & -0.813 & $-0.892 * * *$ & 0.079 & -0.436 & $-0.639 * * *$ & $0.203 * *$ & -0.086 & $-0.286 * * *$ & $0.200 * *$ \\
\hline Netherlands & -0.638 & $-0.608 * * *$ & -0.029 & -0.398 & $-0.504 * * *$ & 0.106 & -0.282 & $-0.368 * * *$ & 0.086 \\
\hline Belgium & 0.888 & $0.851 * * *$ & 0.037 & 0.934 & $0.920 * * *$ & 0.014 & 0.937 & $0.947 * * *$ & -0.010 \\
\hline France & 0.470 & $0.417 * * *$ & 0.053 & 0.439 & $0.341 * *$ & 0.098 & 0.477 & $0.388 * * *$ & 0.089 \\
\hline Switzerland & -1.400 & $-1.195 * * *$ & -0.205 & -1.047 & $-1.106 * * *$ & 0.059 & -0.882 & $-0.999 * * *$ & 0.117 \\
\hline Austria & 1.879 & $1.899 * * *$ & -0.020 & 1.223 & $1.177 * * *$ & 0.046 & 0.657 & $0.698 * *$ & -0.041 \\
\hline Italy & 0.275 & 0.150 & 0.125 & 0.307 & 0.169 & 0.138 & 0.393 & 0.163 & $0.231 * *$ \\
\hline Spain & 0.279 & 0.095 & 0.184 & 0.196 & -0.054 & $0.250 * *$ & 0.353 & 0.117 & $0.235 * *$ \\
\hline Greece & 0.930 & $0.990 * * *$ & -0.060 & 0.679 & $0.651 * * *$ & 0.028 & 0.806 & $0.708 * * *$ & 0.098 \\
\hline England & 0.160 & $0.298 * *$ & -0.138 & 0.286 & $0.175 * *$ & 0.111 & 0.275 & 0.074 & $0.202 * *$ \\
\hline
\end{tabular}

Note: All amounts are in thousands of PPP-adjusted dollars. For variable definitions, please see the Data Appendix. All decompositions for US regions refer to differences with respect to the Midwest, while for European countries to differences with respect to Germany. Quantiles are computed among owners of each asset. ***, **, * denote significance at $1 \%$, $5 \%$ and $10 \%$, respectively. Standard errors computed using 100 bootstrap replications. 
Table 7: Coefficient Effects Related to Selected Economic Indicators (amounts)

\begin{tabular}{|c|c|c|c|c|c|c|}
\hline \multirow[b]{3}{*}{ Indicator } & \multicolumn{6}{|c|}{ Differences due to Coefficients } \\
\hline & \multicolumn{2}{|c|}{ 10th percentile } & \multicolumn{2}{|c|}{ 50th percentile } & \multicolumn{2}{|c|}{ 90th percentile } \\
\hline & Coefficient & Std. Error & \multicolumn{2}{|c|}{ Coefficient Std. Error } & \multicolumn{2}{|c|}{ Coefficient Std. Error } \\
\hline & \multicolumn{6}{|c|}{ Panel A. Stocks } \\
\hline Market capitalization to GDP ratio & -0.0052 & $0.0006 * * *$ & -0.0069 & $0.0015 * * *$ & -0.0072 & $0.0007 * * *$ \\
\hline Internet Connections & -0.0010 & $0.0004 * * *$ & -0.0008 & 0.0005 & -0.0014 & $0.0002 * * *$ \\
\hline Antidirector Rights Index & -0.1375 & $0.0246 * * *$ & -0.1648 & $0.0763 * *$ & 0.0002 & 0.0314 \\
\hline Country Index of Interpersonal Trust & -0.0051 & $0.0014 * * *$ & -0.0043 & $0.0025 *$ & 0.0001 & 0.0017 \\
\hline$R 2$ & 0.94 & & 0.87 & & 0.96 & \\
\hline
\end{tabular}

Panel B. Own Business

\begin{tabular}{|c|c|c|c|c|c|c|}
\hline Tax Burden & 0.0097 & $0.0040 * *$ & 0.0063 & 0.0062 & 0.0131 & $0.0049 * * *$ \\
\hline Difficulty in Getting Credit & -0.0017 & 0.0200 & -0.0505 & $0.0167 * * *$ & -0.0192 & 0.0130 \\
\hline Difficulty in Trading Across Borders & -0.0004 & 0.0095 & 0.0212 & $0.0084 * *$ & 0.0048 & 0.0079 \\
\hline$R 2$ & 0.21 & & 0.66 & & 0.46 & \\
\hline & \multicolumn{6}{|c|}{ Panel C. Home } \\
\hline Housing Price Index (harmonized) & 0.0379 & $0.0062 * * *$ & 0.0343 & $0.0052 * * *$ & 0.0093 & 0.0614 \\
\hline VAT on New Homes & 0.0346 & $0.0098 * * *$ & 0.0295 & $0.0059 * * *$ & 0.0267 & 0.0166 \\
\hline$R 2$ & 0.82 & & 0.90 & & 0.96 & \\
\hline
\end{tabular}

Note: Robust regression estimates of estimated differences in asset distribution due to coefficients on various indicators. $* * *, * *, *$ denote significance at $1 \%, 5 \%$ and $10 \%$, respectively. 


\section{Endnotes}

1 Theory and country-level data on the structure of household portfolios are presented in the contributions contained in Guiso, Haliassos, and Jappelli (2001); and in the review paper of Haliassos (2008). Retirement accounts were a major factor promoting stockholding participation in the US. Limited stockholding participation in the early to mid 1980s was documented in US data by King and Leape (1984), Mankiw and Zeldes (1991), and Haliassos and Bertaut (1995). A number of authors have recently explored determinants of participation in stockholding. See, for example, Haliassos and Bertaut (1995), Cocco et al. (2005), Heaton and Lucas (2000a,b), Gollier (2001), Campbell and Viceira (2002), Haliassos and Michaelides (2003), and Gomes and Michaelides (2005). Bilias et al. (2006, 2010) explore effects of increased participation on the distribution of wealth and stock trading patterns, respectively. Campbell (2006) discusses stockholding participation, as well as underdiversification, and mortgage behavior of households, while reviewing the relevant literature. Campbell and Cocco (2003) study optimal mortgage choice, while Cocco (2005) studies effects of housing on the composition of the financial portfolio.

2 Albrecht et al. (2003), using counterfactual decompositions, find evidence that the gender wage gap is increasing at higher percentiles of the wage distribution in Sweden. For a recent study on trends in US wage inequality in the last forty years see Autor et al. (2008). Recently, counterfactual techniques were used to examine international differences in gender wage gaps or labor status dynamics and relate them to country differences in population characteristics or in policies and institutions (see Arulampalam et al., 2007; and Kapteyn et al., 2007).

${ }^{3}$ For recent examples see Albrecht et al. (2003), Machado and Mata (2005), and Gale and Pence (2006).

${ }^{4}$ The SHARE data set and the sources of its funding are fully described in Börsch-Supan et al. (2005). The SHARE data collection has been primarily funded by the European Commission through the 5th framework program (project QLK6-CT-2001-00360 in the thematic program Quality of Life). Additional funding came from the US National Institute on Ageing (U01 AG09740-13S2, P01 AG005842, P01 AG08291, P30 AG12815, Y1-AG-4553-01 and OGHA 04-064). Data collection in Austria (through the Austrian Science Foundation, FWF), Belgium (through the Belgian Science Policy Administration) and Switzerland (through BBW/OFES/UFES) was nationally funded.

${ }^{5}$ Details on asset definitions are provided in the Data Appendix. As will be discussed later, we examine the robustness of our findings by incorporating in net wealth an imputed measure of pension wealth.

${ }^{6}$ Work status is not included in regressions pertaining to private business ownership, in order to avoid potential endogeneity problems arising from the fact that owning a private business typically determines work status.

${ }^{7}$ Rosen and $\mathrm{Wu}$ (2004) provide evidence that households facing health problems are less likely to invest in stocks.

${ }^{8}$ For the effect of cognitive abilities (including recall) on stockholding see Christelis et al. (2006).

${ }^{9}$ Hong, Kubik and Stein (2004) show that households who visit their neighbours more often have a higher propensity to invest in stocks, and they attribute this finding to the possibility that social interactions lower information costs.

${ }^{10}$ In Sweden, 2.5 percentage points of the 18.5 percentage points of lifetime income that are required as contribution to the public retirement scheme are saved and earn interest in a premium reserve account. Those insured can choose an investment manager for their premium reserve account, with the option to invest in stocks. In Denmark, The Special Pension (SP) is a mandatory individual retirement program (second pillar) with an annual contribution rate of $1 \%$ which was introduced in 1999. We are grateful to Julia LeBlanc for providing us with comparative information on pension systems.

${ }^{11}$ Spain and England are the exceptions in this list picked up by our estimates.

${ }^{12}$ See Bogan, 2008, for evidence on the link between stock market participation and Internet use.

${ }^{13}$ We tried a similar exercise by conditioning on ownership of private business instead of the home, but did not find a notable pattern of differences between owners and non-owners of businesses. While substitution between stocks and private businesses is not unlikely and has been noted in the literature for the US (e.g. Heaton and Lucas, 2000b), our failure to find a pattern may be due to the small number of private business owners in our sample. 
${ }^{14}$ See also Albrecht et al. (2003), who use a similar approach to study gender wage discrimination in Sweden.

${ }^{15}$ The thresholds for income and wealth quartiles are defined for the base country or region over all households in the sample. Households in the country or region that is compared to the base are then placed in quartiles according to those thresholds. 


\section{Discussion Paper Series}

Mannheim Research Institute for the Economics of Aging, Universität Mannheim

To order copies, please direct your request to the author of the title in question.

\begin{tabular}{|c|c|c|c|}
\hline Nr. & Autoren & Titel & Jahr \\
\hline 192-09 & Tabea Bucher-Koenen & $\begin{array}{l}\text { Financial Literacy and Private Old-age } \\
\text { Provision in Germany - Evidence from } \\
\text { SAVE } 2008 \text { - }\end{array}$ & 09 \\
\hline 193-09 & $\begin{array}{l}\text { Axel Börsch-Supan, } \\
\text { Martin Gasche, } \\
\text { Michael Ziegelmeyer }\end{array}$ & $\begin{array}{l}\text { Auswirkungen der Finanzkrise auf die } \\
\text { private Altersvorsorge }\end{array}$ & 09 \\
\hline 194-09 & Wolfgang Kuhle & $\begin{array}{l}\text { The Optimum Structure for Government } \\
\text { Debt }\end{array}$ & 09 \\
\hline $195-09$ & $\begin{array}{l}\text { Michela Coppola, } \\
\text { Anette Reil-Held }\end{array}$ & $\begin{array}{l}\text { Dynamik der Riester-Rente: Ergebnisse aus } \\
\text { SAVE } 2003 \text { bis } 2008\end{array}$ & 09 \\
\hline 196-10 & $\begin{array}{l}\text { Alexander Ludwig, } \\
\text { Thomas Schelkle, } \\
\text { Edgar Vogel }\end{array}$ & $\begin{array}{l}\text { Demographic Change, Human Capital and } \\
\text { Welfare }\end{array}$ & 10 \\
\hline $197-10$ & $\begin{array}{l}\text { Axel Börsch-Supan, } \\
\text { Martin Gasche }\end{array}$ & Zur Sinnhaftigkeit der Riester-Rente & 10 \\
\hline $198-10$ & $\begin{array}{l}\text { Martin Gasche, } \\
\text { Michael Ziegelmeyer }\end{array}$ & $\begin{array}{l}\text { Verbreitung der Riester-Rente - Hat die } \\
\text { Finanz- und Wirtschaftskrise Spuren } \\
\text { hinterlassen? }\end{array}$ & 10 \\
\hline $199-10$ & Martin Gasche & $\begin{array}{l}\text { Rentenanpassung } 2010 \text { - Wem nützt die } \\
\text { Rentengarantie? }\end{array}$ & 10 \\
\hline $200-10$ & $\begin{array}{l}\text { Daniel Kemptner, } \\
\text { Hendrik Jürges, Steffen } \\
\text { Reinhold }\end{array}$ & $\begin{array}{l}\text { Changes in Compulsory Schooling and the } \\
\text { Causal Effect of Education on Health: } \\
\text { Evidence from Germany }\end{array}$ & 10 \\
\hline $201-10$ & $\begin{array}{l}\text { Axel Börsch-Supan, } \\
\text { Martin Gasche }\end{array}$ & $\begin{array}{l}\text { Kann die Riester-Rente die Rentenlücke in } \\
\text { der gesetzlichen Rente schließen? }\end{array}$ & 10 \\
\hline $202-10$ & $\begin{array}{l}\text { Annelies G. Blom, } \\
\text { Edith D. de Leeuw, } \\
\text { Joop J. Hox }\end{array}$ & $\begin{array}{l}\text { Interviewer Effects on Nonresponse } \\
\text { in the European Social Survey }\end{array}$ & 10 \\
\hline $203-10$ & Martin Gasche & $\begin{array}{l}\text { Rentner und Rentnerinnen im deutschen } \\
\text { Sozialversicherungssystem: } \\
\text { Beitragsleistungen und Leistungsbezug }\end{array}$ & 10 \\
\hline 204-10 & $\begin{array}{l}\text { Dimitris Christelis, } \\
\text { Dimitris Georgarakos, } \\
\text { Michael Haliassos }\end{array}$ & $\begin{array}{l}\text { Differences in Portfolios across Countries: } \\
\text { Economic Environment versus Household } \\
\text { Characteristics }\end{array}$ & 10 \\
\hline
\end{tabular}

